
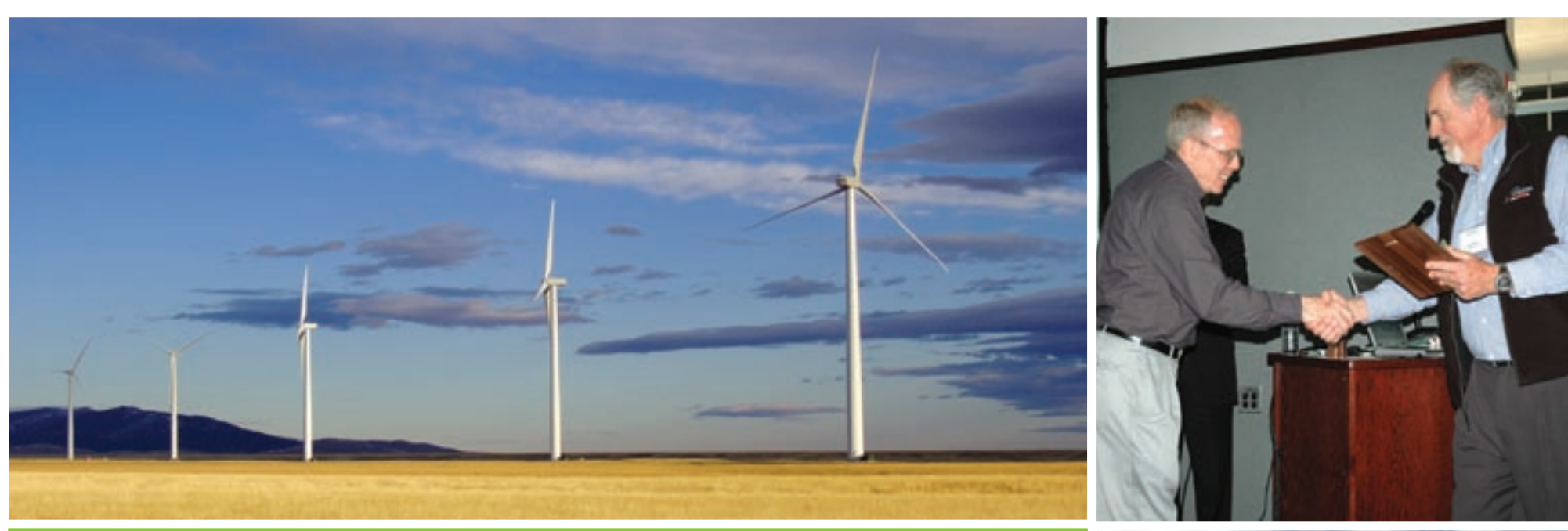

\title{
Wind Powering America FY06 Activities Summary
}
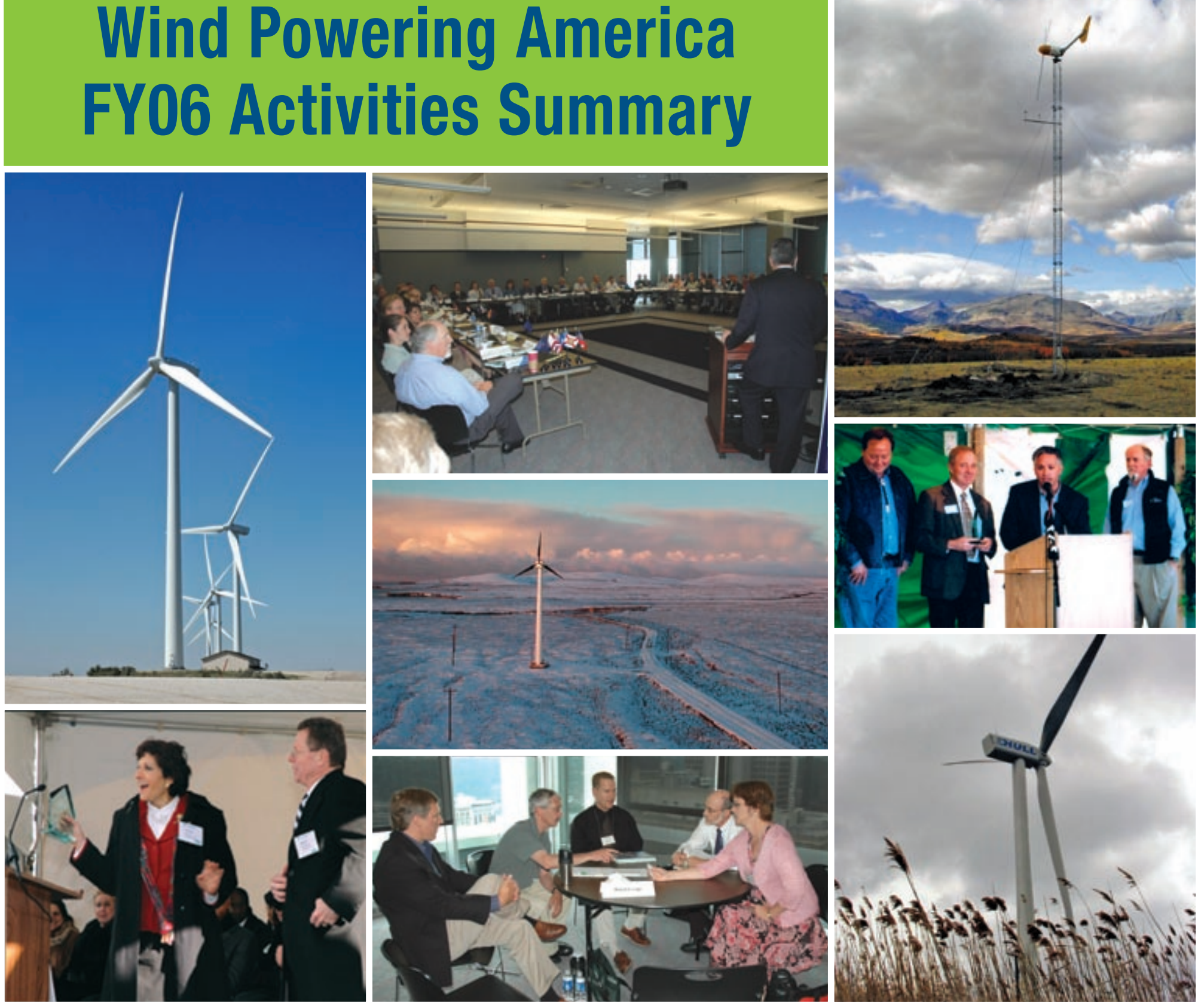

U.S. Department of Energy

1 MORO

C poyjegiages 11 L N J 
Dear Wind Powering America Colleague,

We are pleased to present the Wind Powering America FY06 Activities Summary, which reflects the accomplishments of our state wind working groups, our programs at the National Renewable Energy Laboratory, and our partner organizations. The national WPA team remains a leading force for moving wind energy forward in the United States.

At the beginning of FY07 (October 2006), there were 11,078 megawatts (MW) of wind power installed across the United States, with an additional 3,000 MW projected in both 2007 and 2008. When our partnership was launched in 2000, there were 2,500 MW of installed wind capacity in the United States. In 1999, only four states had more than $100 \mathrm{MW}$ of installed wind capacity. Sixteen states now have more than $100 \mathrm{MW}$ installed. We anticipate five to six additional states will join the 100-MW club in 2007, and by the end of the decade, more than 30 states will have passed the 100-MW milestone. WPA celebrates the 100-MW milestones because the first 100 megawatts are always the hardest and lead to significant experience, recognition of the wind energy's benefits, and expansion of the vision of a more economically and environmentally secure and sustainable future.

WPA continues to work with its national, regional, and state partners to communicate the opportunities and benefits of wind energy to a diverse set of stakeholders. WPA now has 29 state wind working groups (welcoming New Jersey, Indiana, Illinois, and Missouri in 2006) that form strategic alliances to communicate wind's benefits to the state stakeholders. More than 120 members of national and state public and private sector organizations from 34 states attended the 5th Annual WPA All-States Summit in Pittsburgh in June.

WPA's emphasis remains on the rural agricultural sector, which stands to reap the significant economic development benefits of wind energy development. Additionally, WPA continues its program of outreach, education, and technical assistance to Native American communities, public power entities, and regulatory and legislative bodies.

We also took a leadership role in understanding and addressing emerging barriers to wind, including windradar interactions, and we helped secure approval of $\$ 1.5$ billion of new wind projects throughout the Midwest. We continue to work on wind-siting issues with other agencies that have responsibility for development on public lands and protection of wildlife. WPA initiated a Wind for Schools pilot effort in Colorado and will expand it to four to five additional states in 2007. Through these joint efforts and many others, we continue to expand wind energy as a viable option for power generation. The $20 \%$ wind electricity vision that is currently being developed among AWEA, the U.S. Department of Energy, the National Renewable Energy Laboratory, and other stakeholders will require significantly enhanced outreach efforts to communicate the benefits, the required infrastructure upgrades, and the regulatory actions needed to accomplish this promising future for many stakeholder groups in all regions of the country.

We appreciate the commitment of our partners to continue our work together for the benefit of all stakeholders. We share a common vision and hope for the future, and the success is yours to celebrate.

Regards,

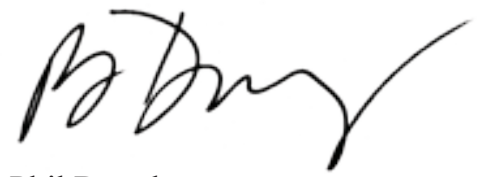

Phil Dougherty WPA National Coordinator

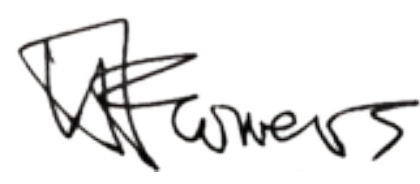

Larry Flowers

WPA National Technical Director 


\section{Contents}

\section{WPA State Activities}

Alaska 1

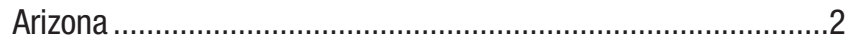

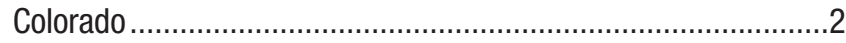

Georgia

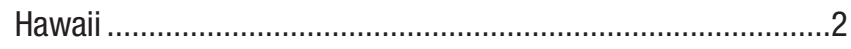

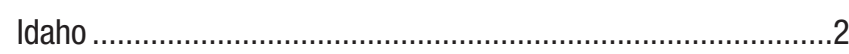

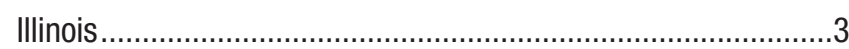

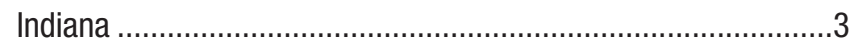

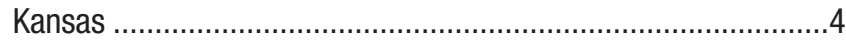

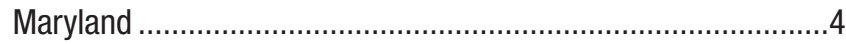

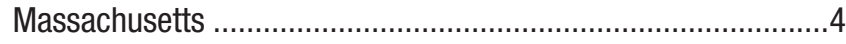

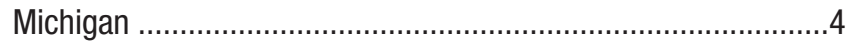

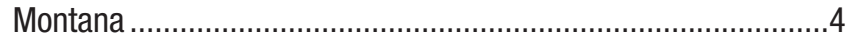

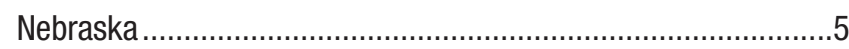

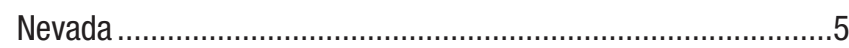

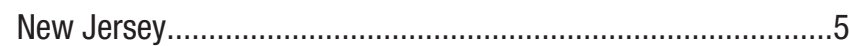

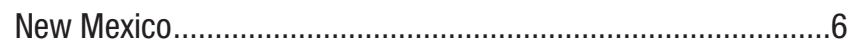

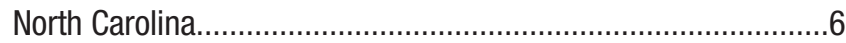

North Dakota .........................................................................

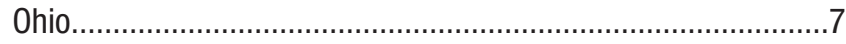

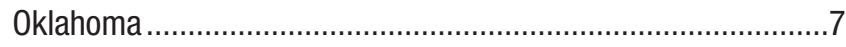

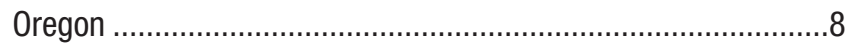

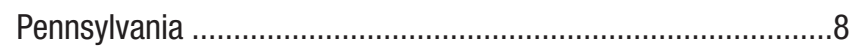

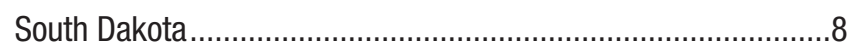

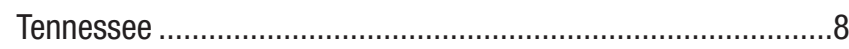

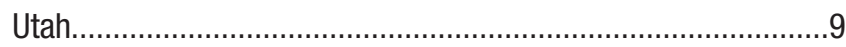

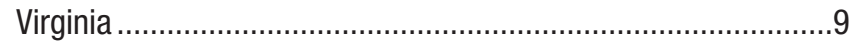

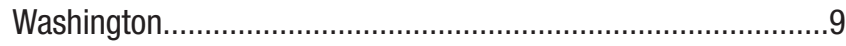

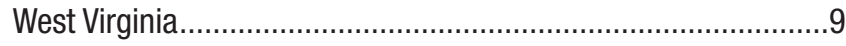

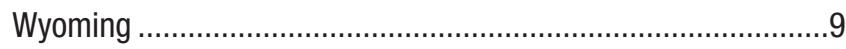

WPA Activities at NREL ....................................... 10

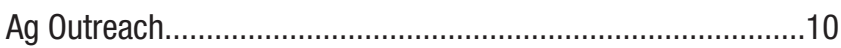

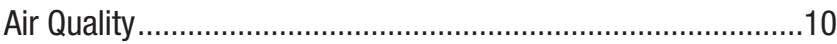

Communications ............................................................... 10

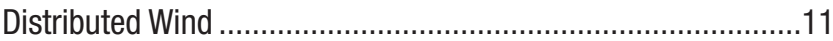

5th Annual WPA All-States Summit Awards ...............................11

USDA Section 9006 (Farm Bill) Support.....................................12

FEMP and Federal Lands........................................................ 12

Native American Program ........................................................12

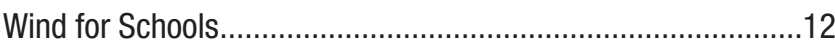

PhD Graduate Tegen to Continue Economic

Development Work at NREL …...........................................13

State Outreach.................................................................

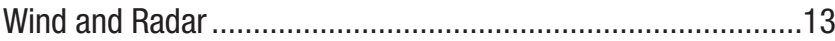

WINDPOWER 2006 Presentations and Posters...........................14

Wind Powering America Web Site............................................16

Wind Resource Assessment ......................................................17

Management Activities..............................................................

Partnerships

American Corn Growers Foundation .........................................17

Technical Assistance Project ....................................................17

WAPA/Public Power Partnerships .............................................18

Cover photos, clockwise, starting top left: The Judith Gap Wind Energy Center in Montana (photo credit: Invenergy LLC/PIX14369); WPA technical director Larry Flowers presents the Midwest Regional Wind Advocacy Award to Tom Wind (photo credit: Robert Gough); 10-kW Bergey wind turbine (photo credit: Doug Nelson/PIX14675); Montana Governor Brian Schweitzer, Bob Quinn of Windpark Solutions, Kevin Smith of Invenergy Wind, and Wind Powering America technical director Larry Flowers celebrate the Carpe Ventem award for the Judith Gap Wind Energy Center; Hull Wind 2 (photo credit: Malcomb Brown/PIX14674); WPA All-States Summit participants engage in a table topic in Pittsburgh (photo credit: Robert Gough); DOE regional office director and WPA steering committee member Ellen Lutz presents the Carpe Ventem Award to Brent Alderfer of Community Energy for the Jersey-Atlantic Wind Farm; The Kumeyaay Wind Power Project east of San Diego is to date the largest wind project on Tribal lands (photo credit: Robert Gough/PIX14792); inside top: The 5th Annual WPA All-States Summit in Pittsburgh (photo credit: Robert Gough); inside bottom: NorthWind 100 turbine in Toksook Bay, Alaska (photo credit: Northern Power Systems/PIX14406). 


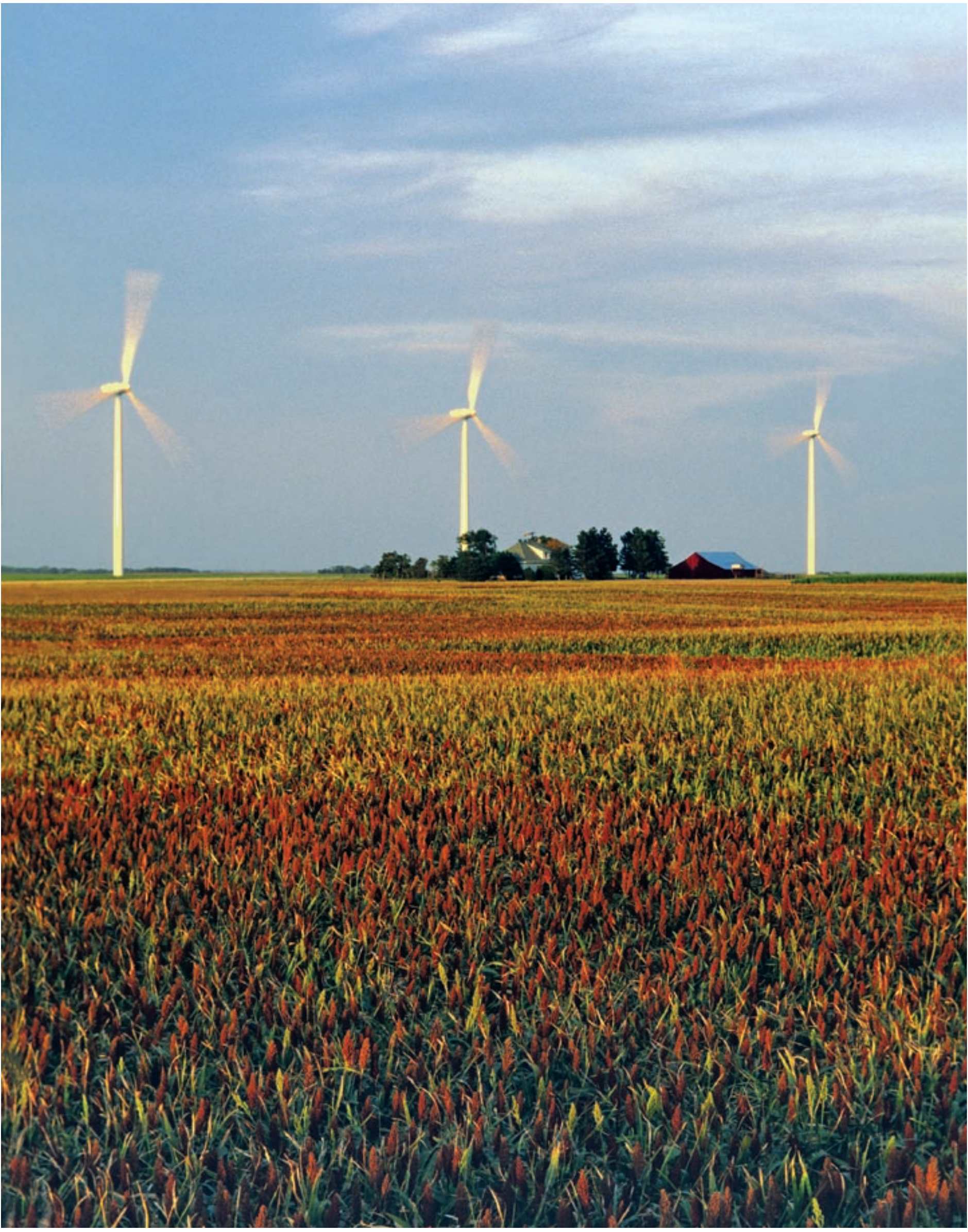

The sun sets on Cecil Herron's milo fields, part of Kansas' Spearville Wind Facility. The wind project, comprised of 67 GE 1.5-MW turbines, is owned and operated by Kansas City Power \& Light. Photo credit: Jenny Hager Photography/PIX14914 


\section{WPA State Activities}

Wind Powering America works to create strategic partnerships at the state level by creating, educating, and supporting state wind working groups. This section summarizes state activities in FY06.

\section{Alaska}

The Alaska Wind Working Group (AWWG) produced the Renewable Energy Atlas of Alaska. A cooperative effort between Renewable Energy Alaska Project (REAP) and the Alaska Energy Authority (AEA), the atlas illustrates the locations of Alaska's renewable energy resources across the state and provides an overview of various renewable energy policy options. Published in early August, the Atlas was completed in time for distribution at the 2nd Annual Alaska Renewable Energy Fair in Anchorage and the Chena Renewable Energy Fair near Fairbanks. More than half of the 7,500 atlases have been distributed to state legislators, utility board members, educators, policymakers, and the general public.
On June 29, 2006, Northern Power, STG Inc., the AEA, the Alaska Village Electric Coop (AVEC), and the Association of Village Council Presidents hosted a Wind-Diesel Conference in Bethel. The event helps community leaders and organizations understand the opportunities, challenges, and processes involved in developing a successful village wind project in Western Alaska. About 50 people participated in the workshop sessions in the morning, and 32 people joined the afternoon field trip to Kasigluk, where three 100-kW Northern Power turbines had just been installed.

The largest public event sponsored by AWWG in 2006 was the Alaska Renewable Energy Fair on August 12. Only in its second year, the fair drew more than 2,000 people, who came to learn about Alaska's vast renewable energy resources. The fair included informational booths; workshops and renewable energy demonstrations; children's educational activities; hybrid, electric, and alternative fuel vehicles; a visual display of average daily

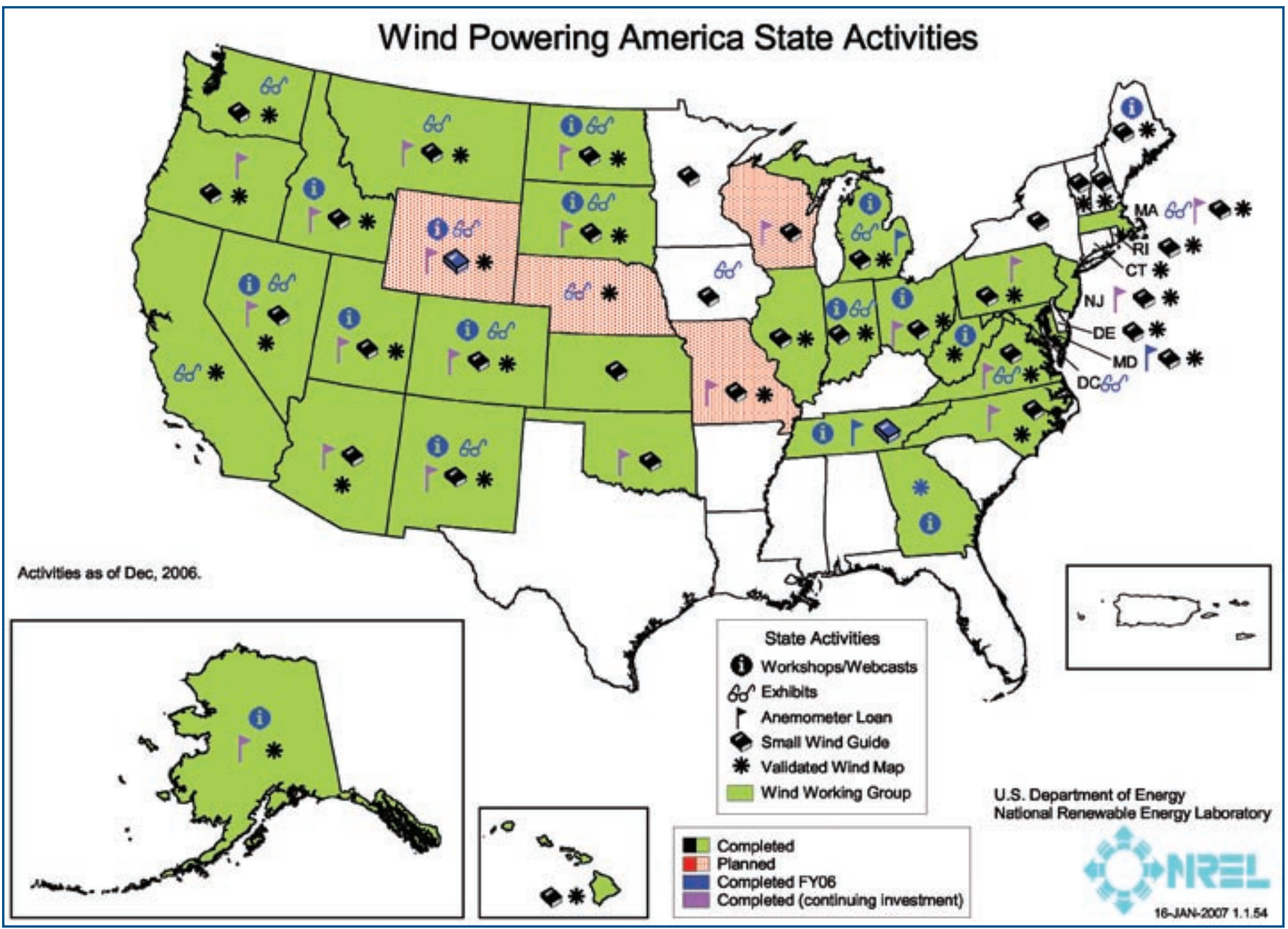


carbon dioxide emissions by country; food and craft vendors; and live music. James Woolsey, former director of the CIA, was the keynote speaker to an audience of nearly 1,000 people, and he answered questions from fair attendees for almost an hour.

\section{Arizona}

Susan Williams, Tom Acker, Grant Brummels, and Megan Greve of Northern Arizona University's Sustainable Energy Solutions Group released Wind Energy Potential in Coconino and Navajo Counties, Arizona: Economic Analysis Using NREL'S JEDI Model with Monte Carlo Simulation and Windy Land Analysis Using GIS. A geographic information system was used to determine the amount of windy land by wind class in each county. Development exclusions were then applied and the developable windy land was determined. The wind energy potential in Coconino County was estimated to be $7500 \mathrm{MW}$, and in Navajo County it was estimated to be $5000 \mathrm{MW}$. The majority of developable windy land, $92 \%$ and $98 \%$ respectively, was Class 3 .

The second analysis determined the economic impact of constructing a wind energy project in each of these counties. Utilizing the National Renewable Energy Laboratory's (NREL's) Jobs, Economic Development, and Impacts (JEDI) model in conjunction with Monte Carlo simulation, economics benefits categorized by jobs, earnings, and economic output were estimated for three sizes of wind energy projects.

\section{Colorado}

As part of its anemometer loan program, the Colorado Governor's Office of Energy Management and Conservation (OEMC) purchased nine anemometer systems with matching funds from DOE and three systems with its own funds. OEMC now has seven 20 -meter systems, three 30 -meter systems, and one 50-meter system.

Based on measurements from the Walsenburg anemometer site, the local high school installed a 900-watt turbine under DOE's Wind for Schools program. NREL provided technical support. Community Energy and NREL purchased the wind turbine and other hardware. Western Resource Advocates is working with Community Energy to market Renewable Energy Certificates from the project. Tom Potter is providing support to the project on a variety of economic development and renewable energy issues. The local community has provided labor, cabling, and trenching; it is also supplying funds for operations and maintenance.

San Isabel Electric Association has purchased three 30-meter towers, for which OEMC is providing data monitoring. Data from these small towers, as well as OEMC's 50-meter tower, show that some of the best wind resources are in San Isabel's service territory. Local developers are pursuing power purchase agreements for large-scale wind farms in the area.

\section{Georgia}

The Georgia Wind Working Group has been developing tools to raise awareness about wind as an energy resource and to educate future host communities, utilities, economic development specialists, and policy makers about wind energy's potential in the state. The Wind Working Group has created a Web site to provide broad public access to information on wind-related topics for Georgia (www.gawwg.org) and has drafted a Georgia wind guidebook.

A comprehensive Georgia wind resource map was completed in September 2006 (with verification for offshore wind performed now and verification for the rest of Georgia expected to be completed by next year).

\section{Hawaii}

In 2006, two new wind power projects came online: the 10.5-MW Hawi Renewable project at Upolu Point on the Big Island and the 30-MW Kaheawa Wind Farm on Maui. In addition, the 20.5-MW Kama'oa Wind Farm at South Point is under construction.

Plans for a 40-MW wind farm with the possibility of a pumped storage hydro component were announced, and a contract was signed for purchase of electricity for a wind farm project to be built on Kauai. Also significant to the development of renewable energy in Hawaii were several new renewable energy incentives and policies contained in the Energy for Tomorrow legislation.

\section{Idaho}

Idaho's annual accomplishments include the repowering of the Lewandowski Wind Farm, located south of Boise. The wind farm is the first and most visible wind farm in the state. Its creator, constructor, and owner Bob Lewandowski died unexpectedly in July, and without maintenance, the turbines stopped a couple of weeks later. At the August 2005 Idaho Wind Power Working Group meeting in Boise, interested parties held a meeting to discuss getting the three 108-kW Micon turbines at the Lewandowski wind farm running again - to help honor Idaho's wind pioneer and to add to rather than detract from wind power's image in Idaho. The group agreed to take action.

Maintenance experts from Montana inspected the turbines and made recommendations. enXco offered to repair the broken yaw drives on Turbine 3 at no charge. In spring 2006, G3 LLC bought the wind farm from Lewandowski's widow and worked for several weeks to repair the turbines. Thanks to a small but dedicated group of people, less than a year after that first meeting the Lewandowski Wind Farm is operating once again and demonstrating wind energy to Idahoans. 


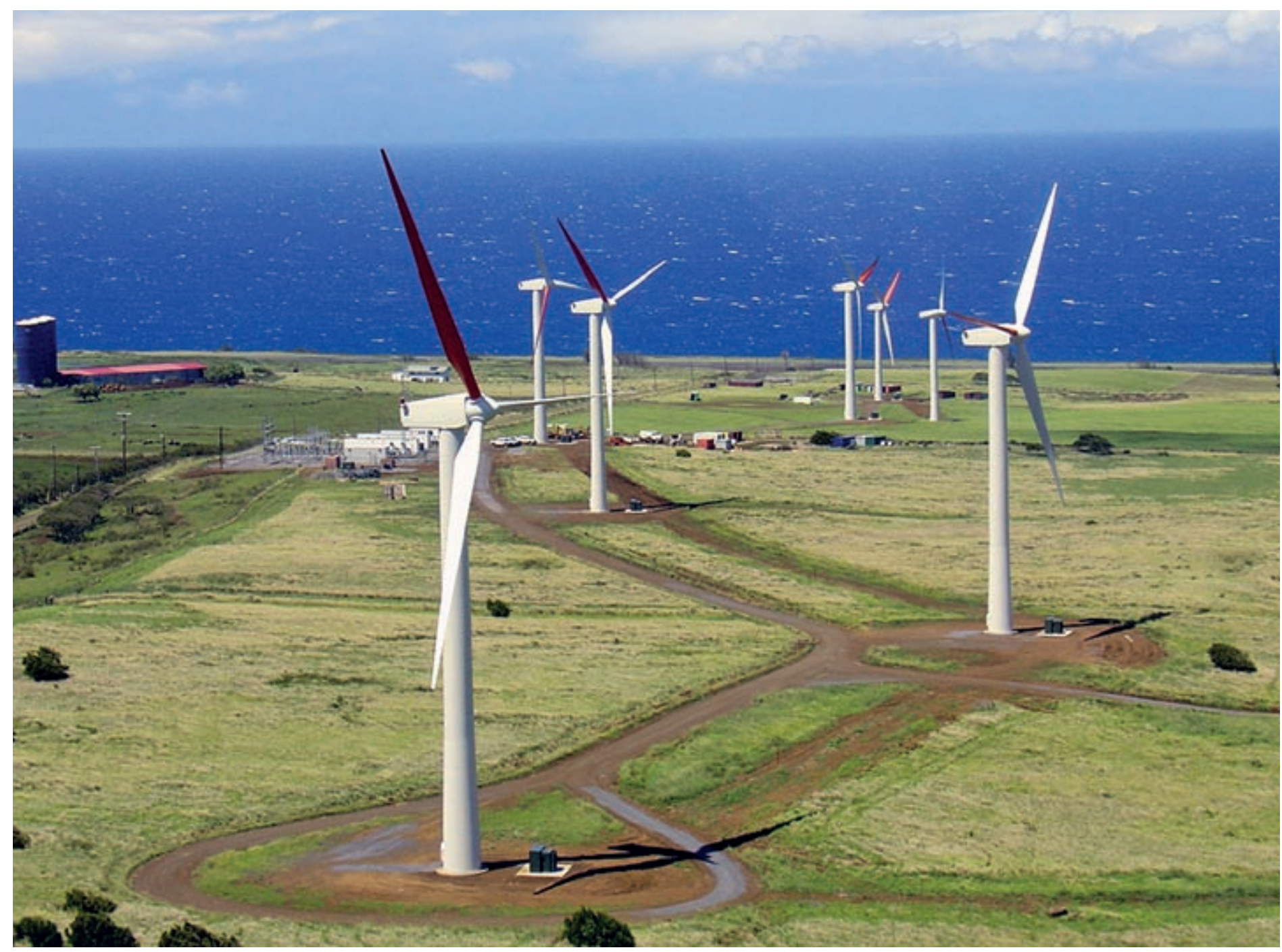

The 10.5-MW Hawi Renewable project at Upolu Point on the Big Island utilizes 16 Vestas V-47 660-kW turbines. Photo credit: Hawaiian Electric Light Company (HELCO)/PIX14697

\section{Illinois}

Horizon Wind Energy (formerly Zilkha) has begun Phase 1 (198 MW) of the Twin Groves project in McLean County. Horizon estimates that more than $100 \mathrm{MW}$ will be installed by the end of 2007, and Phase II is expected to double that.

Also, the Illinois Commerce Commission has started proceedings on an RPS.

\section{Indiana}

The Indiana Wind Working Group (IWWG) worked with a Wayne County stakeholder group to reuse wind anemometer equipment to collect data on a radio station tower north of Richmond, a site that is a few miles south of Indiana's highest point. The stakeholder group consists of Richmond Power \& Light, Earlham College, KICKS96 radio station, the COPE Environmental Center, and a local landowner.

The wind anemometer equipment was previously used to complete the Indiana Tall Tower wind study in 2004 and 2005 and was in storage until this collaborative effort. Richmond Power
$\&$ Light is funding the equipment rehab and data collection, Earlham College students and professors will help collect data, KICKS96 provided room on their station's radio tower, COPE will use the project as an educational tool, and local landowner Bob Wotherspoon provided the spark for the project. The equipment was installed in July 2006, and data are now being collected. Quarterly reports will be made available to the public via the IWWG section of the Indiana Office of Energy \& Defense Development Web site at www.energy.in.gov.

Richmond Power \& Light has expressed interest in adding wind power to its generation mix and saw this project as a first step in the decision-making process.

Also in FY06, IWWG chair Ryan Brown provided technical assistance and direction to staff at Randolph Eastern School Corporation (RESC) for a planned wind/solar hybrid energy system at the K-12 campus. This rural school in Union City intends the project to be educational in nature, introducing and demonstrating alternative energy technologies to students and to the community. The $1-\mathrm{kW}$ wind $/ 920$-watt solar system will be incorporated into the school's science curriculum. The Indiana 
Office of Energy \& Defense Development will provide an Alternative Power \& Energy grant for $50 \%$ of project cost, and Indiana Michigan Power will provide technical and financial assistance. Teacher John Zakelj, RESC's wind champion, has made extensive use of the Web page dedicated to schools on the Wind Powering America site while planning this project.

This project, thought to be Indiana's first wind project at a public school, should be completed in time for an Earth Day 2007 ribbon-cutting celebration. Randolph County may have one of the best wind resources in Indiana.

\section{Kansas}

Nearly 450 people representing 18 states attended the 7 th Annual Kansas Renewable Energy Conference in Topeka on September 26-27, 2006. The conference, devoted to renewable energy and energy conservation, was co-sponsored by Wind Powering America and the Kansas Energy Office (among others). Conference attendees heard presentations on Kansas' newest commercial wind farms: the 150-MW Elk River Wind Project and the 100.5-MW Spearville Wind Energy Facility. Other presentations included an introduction of a new Kansas Community Wind Tool Kit, the John Deere community wind model, small wind turbine applications, school wind, and the role of renewable energy credits in wind projects.

The Kansas Community Wind Tool Kit was unveiled by Joe King of Coriolis in Lawrence. Developed for the Kansas Energy Office and the Kansas Department of Commerce with support from Wind Powering America, the tool kit will enable local leaders to assess their area's potential for potential community wind projects (usually $20 \mathrm{MW}$ or less). The tool kit provides detailed transmission and wind resource information and maps along with potentially sensitive ecological and topical areas and a calculator to allow a financial review of possible projects.

\section{Maryland}

The Maryland Energy Administration (MEA) launched its anemometer loan program in August 2006, in partnership with the James Madison University office of the Virginia Wind Energy Collaborative (VWEC/JMU). VWEC/JMU will be responsible for selecting the initial best candidate sites and for developing the administration of the program. Ultimately, the MEA intends to pass along the administrative duties to a Maryland university.

The Energy Administration successfully worked with Governor Robert Ehrlich to include $\$ 1.5$ million in his proposed budget for the purchase of wind energy for the state's electricity use. Unfortunately, the legislature did not appropriate the spending for renewable electricity. The Administration hired a wind program manager in September 2006 and expects to make significant progress in developing its wind resources in the next year.

In addition, administration staff exhibited its wind activities at the Maryland Farm Bureau conference in December 2005.

\section{Massachusetts}

The Massachusetts Wind Working Group (MWWG) has grown from a small group of wind power enthusiasts to a group of 80 to 90 people who gather for quarterly meetings. Meetings typically include a speaker on a subject useful to the broad range of stakeholders present, such as "Wind Turbine Noise, Infrasound, and Noise Perception" by Tony Rogers of the Renewable Energy Research Laboratory (RERL) at the University of Massachusetts and 'Cooperative Development of Copenhagen's Offshore Wind Project” by Middelgrunden's organizer Jens Larsen. The working group's two subcommittees continue to be active in key issues confronting wind power in the state. The policy committee has worked to keep wind stakeholders informed about important legislation, including repeated attacks on the state's Renewable Portfolio Standard. The education and outreach committee plans to produce an educational video. For more on the MWWG, see www.ceere.org/rerl/mwwg.html

The RERL also operates the state's large anemometer loan program. RERL currently has 20 sets of anemometry installed around the state and in New England. RERL posts this data and data analysis on its Web site at www.ceere.org/rerl/rerl resourcedata.html

\section{Michigan}

The Michigan Wind Working Group (MWWG) began the year with the state's first wind energy conference in Lansing on October 21, which attracted more than 270 attendees. Zoning guidelines for siting wind generators were finalized in December after 2 years of discussion by the MWWG. The Michigan Energy Fair held near Lake Michigan included many sessions and exhibits on wind energy and attracted 2500 attendees over a June weekend. The Michigan State University Extension will begin an anemometer loan program in early 2007.

\section{Montana}

The first two utility-scale wind farm projects in Montana were commissioned and dedicated: the 135-MW Judith Gap Wind Farm near Judith Gap and the 9-MW Horseshoe Bend Wind Farm near Great Falls International Airport. In October 2005, Wind Powering America presented the Carpe Ventem (Seize the Wind) award to Windpark Solutions LLC and Invenergy Wind LLC for their role in developing the Judith Gap project.

Montana local governments applied for \$37 million in Clean Renewable Energy Bonds and presented the applications to Montana Senator Max Baucus in Washington, DC. The application for bond authorization received positive statewide press coverage.

The Montana Public Service Commission adopted rules to implement the Renewable Energy Portfolio Standard passed by the 2005 Montana Legislature. In adopting its rules, the Public Service Commission concluded that the "cost cap" included in 
the Renewable Energy Portfolio Standard bill did not apply to the cost of complying with the standard. The Public Service Commission left the resolution of "cost caps" to the 2007 Legislature rather than impose its own solution through rules.

\section{Nebraska}

The American Corn Growers Foundation (ACGF) brought a wind project development consultant to Nebraska for meetings with the Nebraska Public Power District (NPPD); the Nebraska Electric Generation and Transmission Cooperative, Inc.; and groups interested in more wind farm development in Nebraska. The ACGF effort resulted in a proposed project, but due to changes in the NPPD's executive leadership, the project was delayed and put on hold because of the federal Production Tax Credit window. Numerous other outreach activities include meetings with rural electric cooperatives.

\section{Nevada}

The Nevada State Office of Energy supported the planning and meetings for the Renewable Energy Center for wind activities at the Redfield campus of the University of Nevada. The office was supportive and involved in telephone conference calls regarding the small wind turbine certification program sponsored by NREL and the Interstate Renewable Energy Council (IREC).

Two anemometers were added to the anemometer loan program and sent to Beatty, along with a returned unit for wind evaluation at the old Bullfrog Mine site.

A wind workshop was held in July with 161 in attendance (presentations are available on www.energy.state.nv.us). Before the workshop, representatives from the Bureau of Land Management, U.S. military, Department of Homeland Security, and the Federal Aviation Administration discussed the wind and radar interface, and the National Wind Coordinating Committee held a meeting after the workshop to collaborate on radar and wind on a national scope.

\section{New Jersey}

On December 12, 2005, New Jersey dedicated its first wind power generation facility, the Jersey-Atlantic Wind Farm in Atlantic City. The five 1.5-MW wind turbines power the Atlantic County Utilities Authority Wastewater Treatment Facility, and excess energy is provided to the main power grid. The New Jersey Board of Public Utilities, Office of Clean Energy provided funding for the facility. Wind Powering America presented the Carpe Ventem (Seize the Wind) award to Community Energy Inc. for its role in developing the project.
The New Jersey State Based Anemometer Loan Program is currently monitoring six anemometers in various locations. Because of the demand for additional anemometers, the New Jersey Office of Clean Energy is considering expanding the program with its own Clean Energy funds.

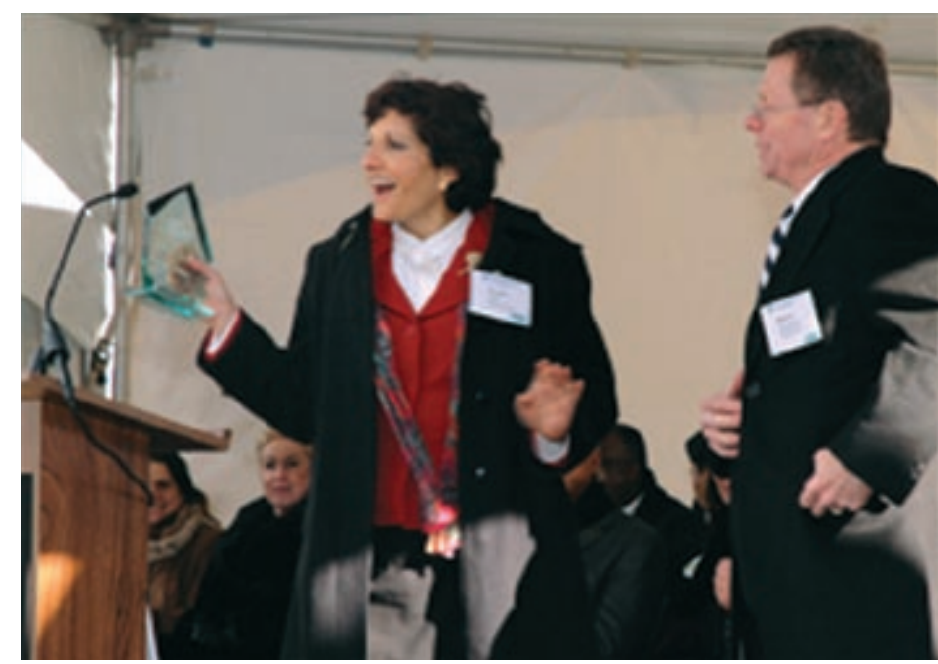

DOE regional office director and WPA steering committee member Ellen Lutz presented the Carpe Ventem Award to Brent Alderfer of Community Energy for the Jersey-Atlantic Wind Farm. 


\section{Western North Carolina Renewable Energy Initiative}

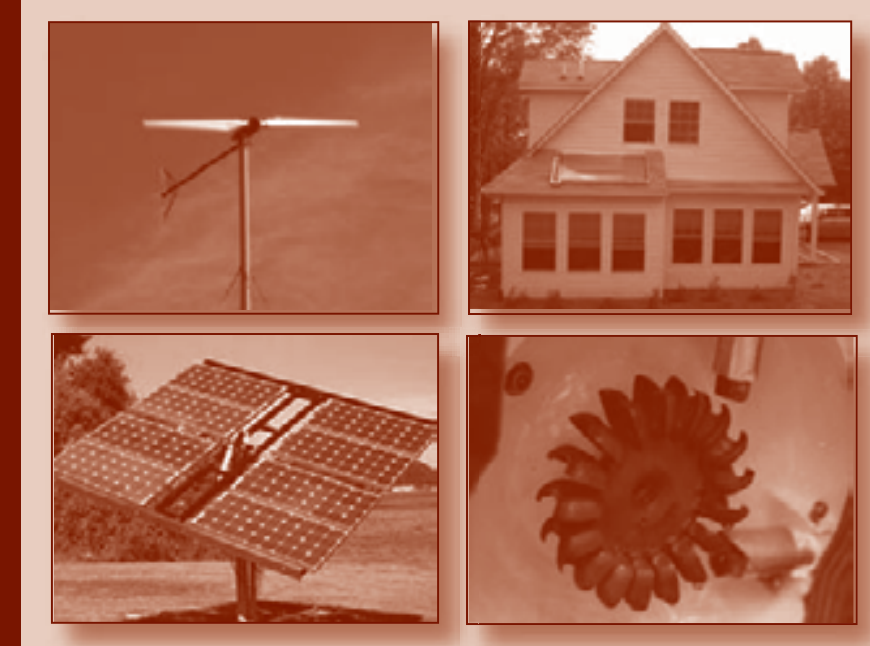

\section{Workshop Series}

Please join us for these exciting workshops in the beautiful North Carolina Mountains.

Saturday, April 22

Introduction to Small Scale Wind Energy

Saturday \& Sunday, May 27 \& 28 Microhydro with Don Harris

Saturday \& Sunday, June 24 \& 25 PV/Wind Installation with Shawn Fitzpatrick

Sunday, August 27

Small Scale Wind Energy at the 2006 SEE Expo

Saturday, September 9

Introduction to Small Scale Wind Energy

Friday evening \& Saturday, September 22 \& 23 Wind Resource Assessment

Saturday \& Sunday, October $21 \& 22$

Small Scale Wind Energy

with Southwest Windpower

\section{Register at \\ wind.appstate.edu \\ or call (828) 262-2933}

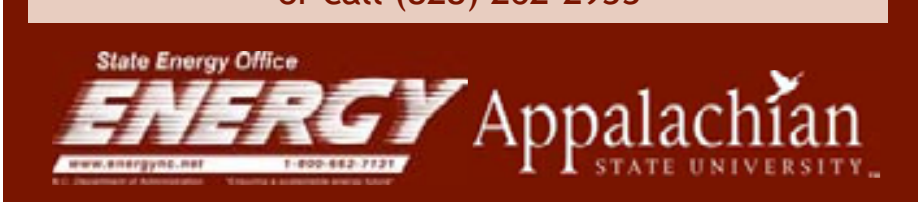

The North Carolina Small Wind Initiative at Appalachian State University conducted six small wind workshops.

\section{New Mexico}

The New Mexico Wind Working Group held five general meetings. The group selected several areas related to wind development within the state on which to focus: legislation being considered by the state, wind resource assessment techniques, outreach, and government grant and loan programs.

In the area of legislation, the group worked with existing renewable energy lobbying efforts within the state. The state legislature held an abbreviated session this year, so few bills were heard in full. Lobbying efforts will continue into the next legislative session.

The task force for evaluating the techniques available for wind resource assessment is comparing information on the techniques being considered.

Outreach efforts included presenting the benefits of wind development for rural communities to several agricultural groups at their annual meetings, speaking at three locations with the USDA's Lenders' Forums, participating in the State of New Mexico's Rural Electric Cooperative task force, and attending Tri-State Generation and Transmission's Members' Contract subcommittee meetings.

\section{North Carolina}

The North Carolina Small Wind Initiative at Appalachian State University (ASU) organized, advertised, and conducted six small wind workshops at the Small Wind Research and Demonstration Facility on Beech Mountain. ASU continues to operate the facility, which is open to the public and set up like an outdoor museum with signage on each turbine and a general wind energy kiosk. ASU has tested and demonstrated 10 turbines at the site (Southwest Windpower supplies the products to demonstrate and test).

The Western North Carolina Anemometer Loan Program (WNCALP) is part of the Small Wind Initiative's effort to increase the use of small-scale wind power in the Southern Appalachian Region. Four sites have been assessed, and data have been posted on the Web at http://www.wind.appstate.edu/ wdata/Index.htm

The group developed and adopted the first North Carolina ordinance related to wind energy, which provides a permitted-use designation for small wind up to $20 \mathrm{KW}$, and a reasonable application process for large wind and a legal ruling indicating that wind turbines (solitary) can be constructed on ridges in Watauga County.

In addition, the Small Wind Initiative has continued its outreach and education efforts, including presentations to community groups, meetings, and conferences (including two presentations at WINDPOWER 2006); providing site assessments and consultations to many individuals interested in wind energy; and writing 


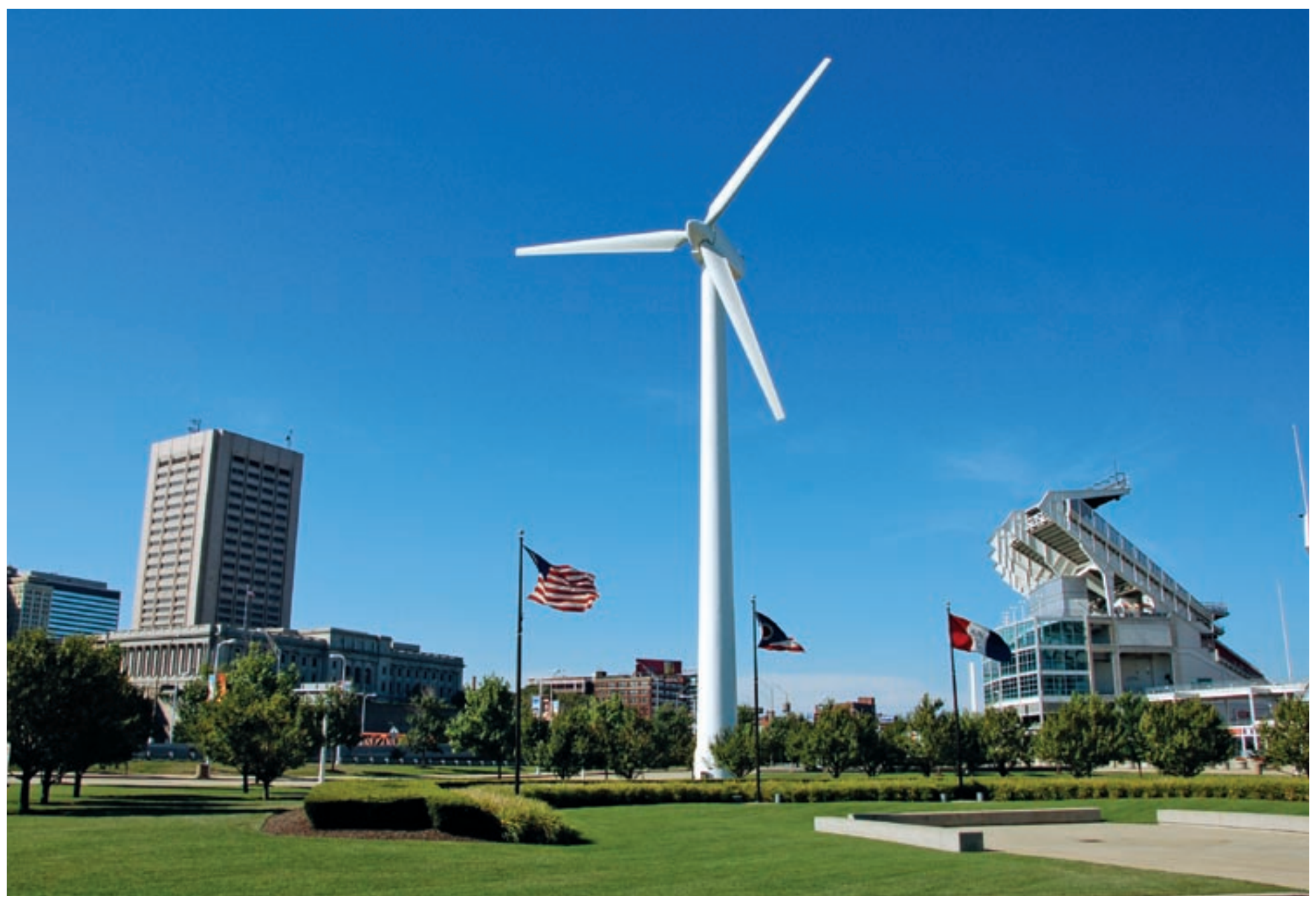

The Ohio Wind Working Group (OWWG) assisted with the installation of an educational, utility-scale Vestas 225-kW wind turbine in downtown Cleveland, located directly in front of the Great Lakes Science Center and next to the Rock \& Roll Hall of Fame and the Cleveland Browns Stadium. Photo credit: Tom Maves/ PIX14827

an article about the Small Wind Initiative for Home Power magazine (published in the June/July 2006 issue).

\section{North Dakota}

The Energy and Environmental Research Center and the North Dakota State Energy Office have participated in three anemometer deployments that have resulted in 24 testing sites in North Dakota. Also, the State Energy Program offered a successful Kid Wind Workshop for 21 teachers in August.

\section{Ohio}

The Ohio Wind Working Group (OWWG) initiated its Anemometer Loan Program in January 2006. Three 50-meter tower kits are available this year, and the OWWG plans to purchase more tower kits next year. Under the program's first request for proposals, the OWWG received nine applications. The successful applicants have been notified, and plans are underway to get anemometer tower kits operational by fall 2006 .

The OWWG assisted in getting an educational utility-scale wind turbine installed in downtown Cleveland on the lakeshore. The refurbished 225-kW Vestas turbine is located directly in front of the Great Lakes Science Center (GLSC). The GLSC attracts thousands of visitors every year and is also located directly next to the Rock \& Roll Hall of Fame and the Cleveland Browns Stadium. The GLSC staff, with assistance from the OWWG, is developing interactive displays and educational exhibits about wind power. (The educational information will include honest facts about the less-than-ideal siting of this turbine.)

\section{Oklahoma}

Oklahoma was featured as the showcase state in the November 2005 edition of North American Windpower magazine. Oklahoma Wind Power Initiative (OWPI) personnel were involved with several articles, and the OWPI wind resource map was featured (the electronic copy is available at http:// www.nawindpower.com/naw/efeature/NAW_efeature.html)

The group was heavily involved in state outreach in the past year, including:

- Farm Bill workshops in Stillwater and Altus

- Rural workshops in Kingfisher and Alva 
- An OWPI exhibit at the 2005 Oklahoma Farm Bureau Expo in Oklahoma City $(10,000$ in attendance)

- Seven presentations and conferences in Purcell, Oklahoma City, Norman, and Sayre.

Also, OWPI continues to distribute the bi-monthly Oklahoma WinCharger newsletter to more than 2000 people in Oklahoma and across the nation. OWPI also plans to debut a guide to community wind projects.

\section{Oregon}

The Oregon Department of Energy (ODOE) organized a workshop in Rockaway Beach in October 2005 in cooperation with Tillamook and Clatsop County officials. The goals of this workshop were (1) to transfer the knowledge gained with the work to develop small community wind energy projects in north-central Oregon to the northern Oregon coastal area, and (2) to encourage discussion on how to locate small wind farms without unduly affecting the aesthetic quality of the coastal region. The approximately 80 attendees represented a broad spectrum of stakeholders, including local citizens interested in renewables, public officials, utility personnel, and wind farm developers.

ODOE organized the Information Workshop on Renewable Energy Production Payments in Salem in April 2006 because the Governor's Renewable Energy Action plan includes provisions to:

1) Assess the feasibility and effectiveness of production-based incentives for electricity generated by small- to medium-scale renewable resource facilities

2) Assess the feasibility of a state Renewable Portfolio Standard and compare it with production-based incentives as to its effectiveness to encourage renewable energy development.

The Governor has formed a Renewable Energy Working Group (REWG) that is charged with the development of an RPS for Oregon's next legislative session, which starts in January 2007. Members of the Oregon Wind Working Group who were involved in community wind for the past few years have been active in developing language to be included in an RPS. Preliminary recommendations include using the current renewable energy portion of the 3\% Public Purpose Charge exclusively for Community Energy development of systems of $20 \mathrm{MW}$ or less.

\section{Pennsylvania}

Wind partners in Pennsylvania developed a model wind ordinance based on discussions originated by the Pennsylvania Wind Working Group. This ordinance was unveiled in spring 2006 and is available on the group's new Web site: www.pawindenergynow.org.

In June 2006, Pennsylvania hosted this year's American Wind Energy Association's WINDPOWER 2006 Conference and
Exhibition in Pittsburgh. Prior to the event, the Pennsylvania Wind Working Group presented to the Fourth Small Wind State Stakeholders Meeting to discuss state incentives for small wind system installations.

\section{South Dakota}

In October 2005, more than 350 people attended a wind energy workshop in Brookings, and another 200-plus people joined via a live Webcast. More than 10 town meetings were held in various parts of rural South Dakota, and the Wind Working Group sponsored a booth at the Sioux Falls Home Show, Black Hills Home Show, Sioux Empire Fair, Brown County Fair, South Dakota State Fair, and Dakotafest.

To date, South Dakotans have requested more than 400 copies of the Windmills to Wind Farms DVD. In addition, the Web site www.sdwind.com is updated monthly.

\section{Tennessee}

The Tennessee Wind Working Group (TWWG) hosted an open house for commercial wind developers on August 25 and 26, 2006, for the top Wind Development Zone in Tennessee. The two-day meeting included local stakeholders such as the site land owner, the mayor of Mountain City, five Johnson County council members, the general manager of the local electric cooperative, and a group of wind developers, including AES, Invenergy, and Magellan Resources. Presentations included sharing 7 years of site wind data, discussion of two possible transmission plans and the already-built access roads, the Environmental Assessment previously completed on the site by TVA, and the property tax

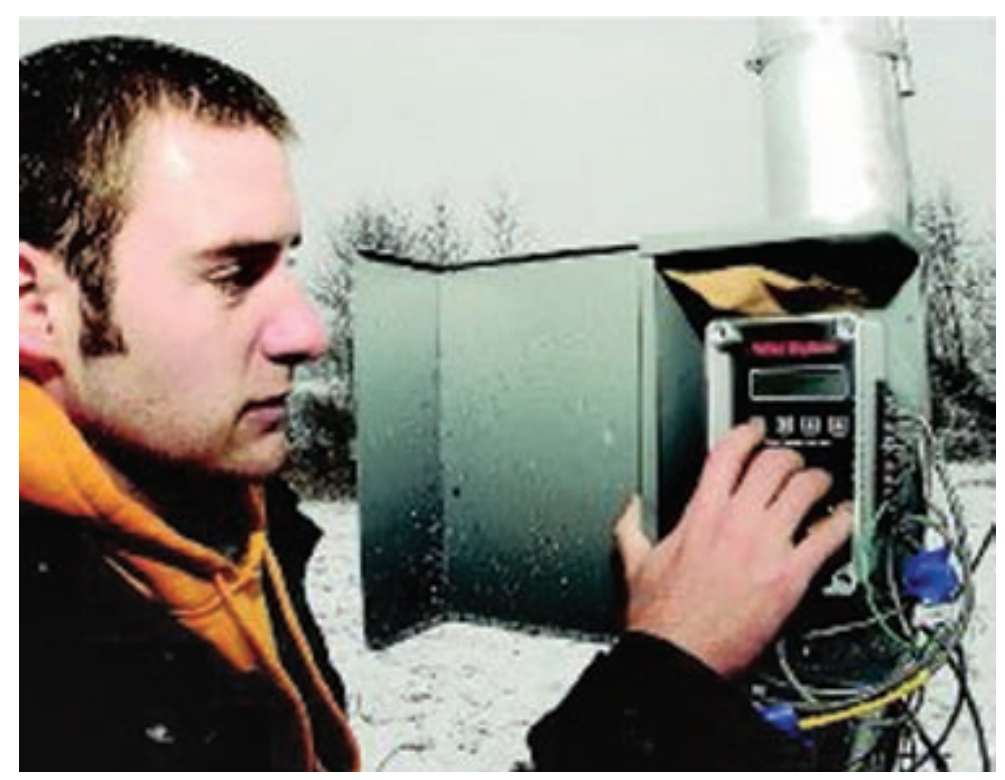

Tennessee Wind Working Group member Brandon Blevins explains how the data are stored during an anemometer raising in February 2006 in the Town of Jonesborough. Photo credit: Southern Alliance for Clean Energy/PIX14873 
law that gives a $66 \%$ exemption on appraisals for commercial wind energy systems in the State of Tennessee. The discussion that followed the presentation focused on the strong local political support for a commercial wind site and the low permitting requirements in the county. Discussion also focused on the promising need for more wind tags in the Southeast for volunteer markets and TVA's Dispersed Power Production Guidelines. After the formal meeting, the land owner and wind developers were treated to a dinner sponsored by the Tennessee Valley Infrastructure Group (TVIG).

The TWWG also has a small anemometer loan program, undertakes an annual fall wind workshop mostly focusing on residential-scale wind, performs site visits for interested land owners (as limited resources allow), and is exploring options for an updated wind resource map.

\section{Utah}

The State Energy Program contracted with Utah Clean Energy to prepare and host three USDA Section 9006 Farm Bill workshops across the state. The workshops were well attended. The program also organized a successful meeting with state legislators in February 2006. The program is continuing its Wind Working Group and Anemometer Loan Program.

\section{Virginia}

The Virginia Wind Energy Collaborative (VWEC) released a GIS-based resource that facilitates the inclusion of environmental information into macro-siting decisions for utility-scale wind power development. This resource includes a Landscape Classification System that provides contact information for agencies and organizations that have environmental conservation and protection mandates potentially affected by the development of wind power. The package is available at http://vwec.cisat.jmu. edu/gis_lcs.htm

It is anticipated that 10 small wind turbines will be installed with support from the Virginia Small Wind Incentives Program by the end of 2006. In July, a 1-kW Bergey XL.1 was installed in Northumberland County on a temporary tower for demonstration through September. The turbine is intended to help assuage concerns of residents and county board members regarding visual and auditory impacts. Two VSWIP awardees, Gordon and Judy Burgess, and Joe and Quincy Umphlette, have experienced some local resistance to their planned installations. The final round of funding was awarded in January 2006.

\section{Washington}

The Washington Energy Program, in cooperation with the State Department of Revenue, held three public and stakeholder meetings in Olympia and Spokane on implementation of a 12-centsper-kWh production incentive for wind energy systems installed on non-utility property (this is intended to encourage community wind and wind projects on school grounds). These production credits will be available for 9 years. This is a state tax credit allocation that will raise as much as $\$ 120$ million for renewable energy projects.

Washington State University, in conjunction with the Washington State PUD Association and local utilities, organized and conducted wind energy workshops in Goldendale, West Richland, Walla Walla, and Wenatchee.

\section{West Virginia}

A West Virginia Wind Working Group meeting was held at the Canaan Valley Resort and Conference Center on October 19, 2005. There were 33 attendees.

On behalf of the working group, coordinator Patrick Mann presented pro-wind testimony before the National Academies Committee on Environmental Impacts of Wind Energy Projects in Charleston in December 2005.

\section{Wyoming}

Wyoming organized a Wind Working Group and an anemometer loan program, worked with the USDA Rural Development Program to develop successful Value-Added Producer Grant applications for the anemometer loan program, and sponsored the Roping the Wind renewable energy conference.

The group also participated in wind workshops in Rock Springs, Kaycee, Laramie, and Wheatland and presented diverse topics to agricultural groups at the Wyoming State Fair: wind project types (distributed, community, and utility scale) and their potential; the state's anemometer loan program; transmission issues and access; USDA funding opportunities; and traps to watch out for when signing contracts with developers. The primary audience was agriculture producers with potential wind prospects and interest in developing their properties. 


\section{WPA Activities at NREL}

This section summarizes WPA activities conducted by teams at the National Renewable Energy Laboratory in FY06.

\section{Ag Outreach}

The Wind Powering America team at NREL continues to develop and strengthen alliances with the agricultural sector and organizational alliances, including 25x'25, the American Corn Growers Foundation, and the National Association of Counties. Members focused on an increased presence at agricultural events in FY06:

- National Association of Farm Broadcasters in Kansas City, Missouri in November

- Montana Agricultural and Industrial Expo in Great Falls in January

- Harvesting Clean Energy in Spokane in February

- 25x’25 National Summit in DC in March

- Community Wind Energy in Des Moines in March

- Harvesting Energy Network in Loveland, Colorado in March

- Commodity Classic in Anaheim in March

- Farm Progress Show in Amana, Iowa in August.

NREL lead: Marguerite Kelly

\section{Air Quality}

In January 2006, the U.S. DOE and WPA co-sponsored a Webcast with the American Wind Energy Association and State and Territorial Air Pollution Program Administrators (STAPPA) and the Association of Local Air Pollution Control Officials (ALAPCO), Incorporating Renewable Energy under the Clean Air Interstate Rule (CAIR). Presentations, additional information, and background on CAIR can be found at www.windpoweringamerica.gov/policy cap trade.asp

NREL lead: Lori Bird

\section{Communications}

Among other outreach activities, Wind Powering America coordinated and shipped an exhibit and materials to 17 events in California, Colorado, DC, Iowa, Missouri, Montana, Nevada, New Mexico, Ohio, Pennsylvania, and Washington. The program also provided handout materials for 11 State Wind Working Group events in Colorado, Indiana, Montana, Michigan, Nebraska, Ohio, South Dakota, Utah, and Virginia.

On the day following WINDPOWER, the WPA program convenes its Annual State Summit. The Summit provides WPA's network of state wind working groups, state energy officials, DOE and national lab WPA representatives and its professional and institutional partners an opportunity to review successes, opportunities, and challenges for wind at the state level. The NREL team planned and organized the 5th Annual WPA All-States Summit in Pittsburgh and produced handout materials and awards.

This year's participants shared strategies and lessons learned, reviewed priority activities and topics, and celebrated and recognized accomplishments among peers. The day began with an energy plenary presentation from Sue Tierney, followed by panels

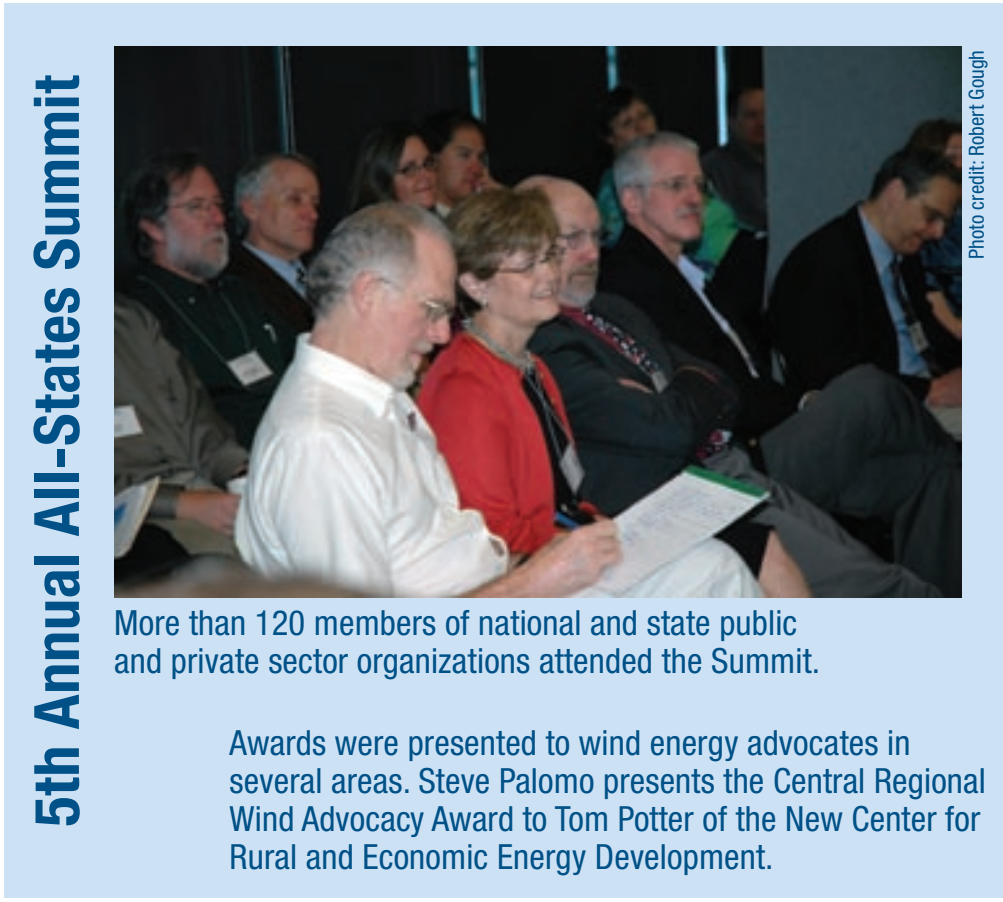

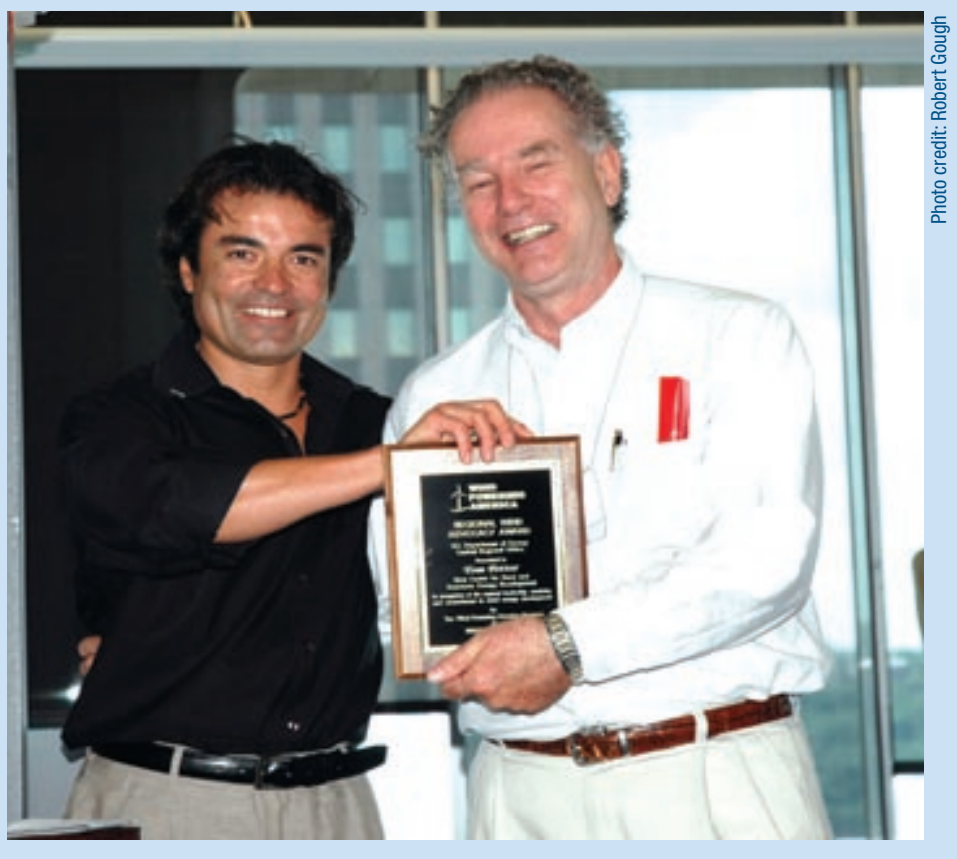

Wind Powering America FY06 Activities Summary 
on comparative economics, economic development, and siting. An awards luncheon was followed by regional breakout sessions. Participants then had the chance to visit six experts of their choice on topics that included avian and wildlife issues, siting, transmission, community wind, small wind, Native American projects, operating impacts, utility myths, regulators, radar, Wind Energy Works, interconnection, wind resources and mapping, air quality and the wind nexus, co-ops, the Farm Bill, offshore wind, state policy options, deliberative polling, wind for schools, wind/hydro integration, the JEDI tool and economic development, Clean Renewable Energy Bonds, and the 25x'25 initiative. The day concluded with a reception.

NREL lead: Ruth Baranowski

\section{Distributed Wind}

WPA team members furthered the development of small wind turbines across the United States in FY06 by working with diverse stakeholders, including solar organizations, rural electric co-ops, farmers, state conference attendees, and the media. Highlights include:

- Presented workshops and chaired sessions at ASES 2006 in Denver

- Presented distributed wind and Section 9006 U.S. Farm Bill information to audiences in Colorado, Massachusetts, Utah, Wyoming, Nevada, Iowa, and Wisconsin

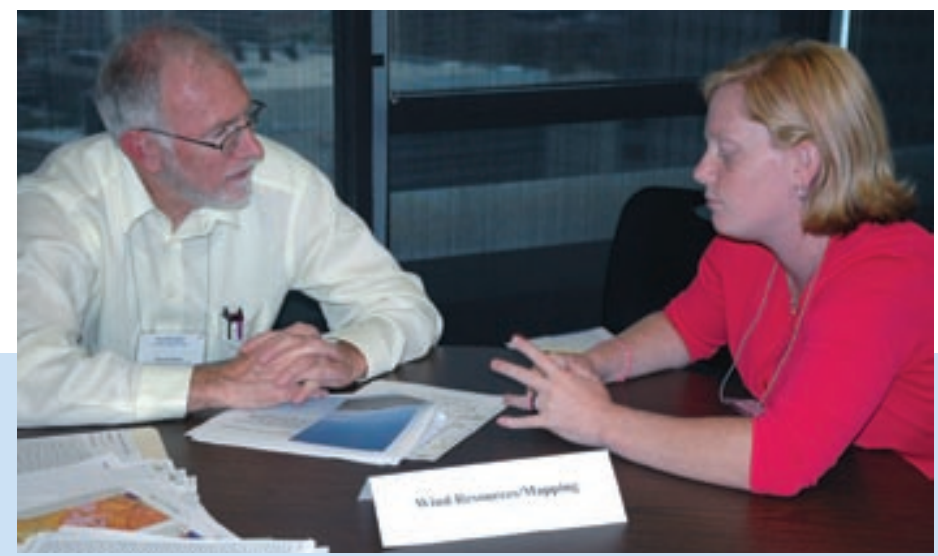

Dennis Elliott of the NREL Wind Resource Assessment team discusses mapping.

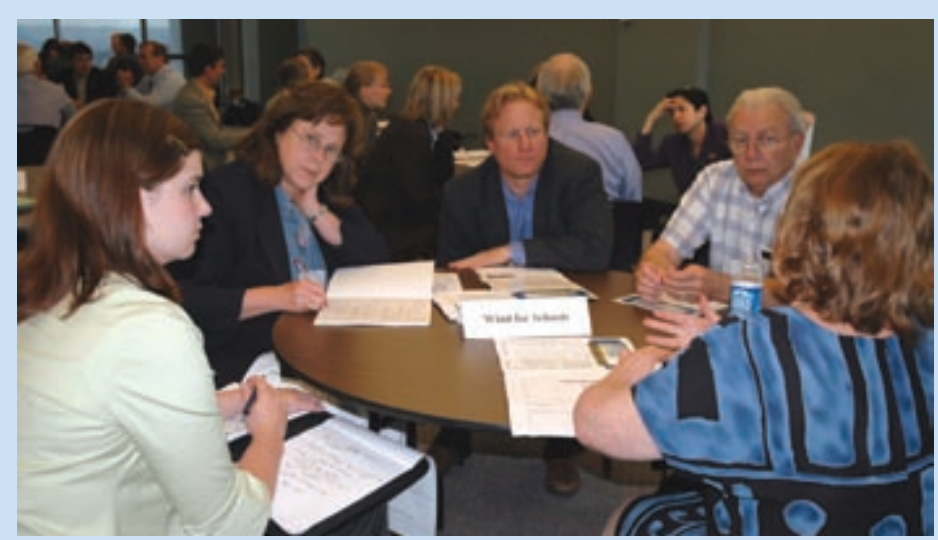

Marguerite Kelly of NREL speaks to a group about wind for schools.
- Performed technical review for 48 Section 9006 proposals.

NREL lead: Trudy Forsyth

NREL contractors: Kidwind Project, Interstate Renewable Energy Council

\section{5th Annual WPA All-States Summit Awards}

\section{Young Wind Advocate Award:}

Suzanne Tegen

\section{Outstanding State Wind Working Group:}

Van Jamison and Georgia Brensdal of Montana

\section{Small Wind Advocate:}

Heather Rhoads-Weaver

\section{Central Regional Wind Advocacy Award:}

Tom Potter, New Center for Rural and Economic

Energy Development

\section{Mid-Atlantic Regional Wind Advocacy Award: Mitch King, Old Mill Power Company}

\section{Midwest Regional Wind Advocacy Award:}

Tom Wind, Wind Utility Consulting Service

\section{Northeast Regional Wind Advocacy Award: John Mcleod, Hull Municipal Light Plant}

\section{Southeast Regional Wind Advocacy Award:} Larry Shirley, North Carolina State Energy Office

\section{Western Regional Wind Advocacy Award:}

Warren Bollmeier, Hawaii Renewable Energy Alliance

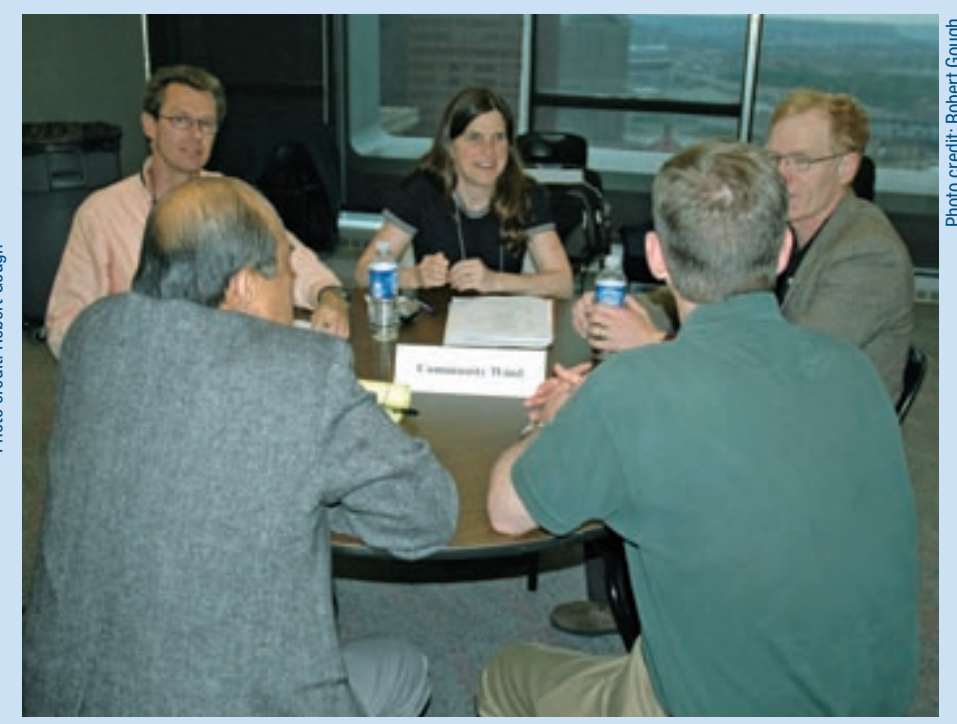

Participants chose six table topic talks to attend. Experts spoke with each group for 20 minutes. Lisa Daniels of Windustry speaks with a group about community wind. 


\section{USDA Section 9006 (Farm Bill) Support}

The USDA's Section 9006 program experienced a significant increase in the number of small wind applications submitted in FY06. NREL experts completed technical reviews on 26 large wind and 49 small wind applications submitted under the program. In addition to providing technical reviews, NREL experts also provided support in developing program outreach materials. With the assistance of NREL experts, the 9006 Small Wind Sample Application was revised to meet the requirements of the program final rule approved in 2005.

A simplified small wind technical worksheet was also developed for projects with total costs of $\$ 200,000$ or less to help streamline the technical review process for both applicants and reviewers. NREL representatives also attended the WINDPOWER 2006 conference in Pittsburgh and presented a poster describing the various types of financial assistance available through the Section 9006 program.

NREL lead: Roya Stanley

\section{FEMP and Federal Lands}

The Federal Energy Management Program (FEMP) team provided ongoing support to several federal wind projects during FY06.

Wind data are being collected and analyzed at the U.S. Coast Guard's Kodiak Launch Complex in Kodiak, Alaska, with a met tower that was installed in 2004. The met tower was relocated to another location onsite in 2005, and data collection and analysis continue.

The Bureau of Land Management (BLM) partnered with DOE in 2003 and 2004 to explore private wind development on leased

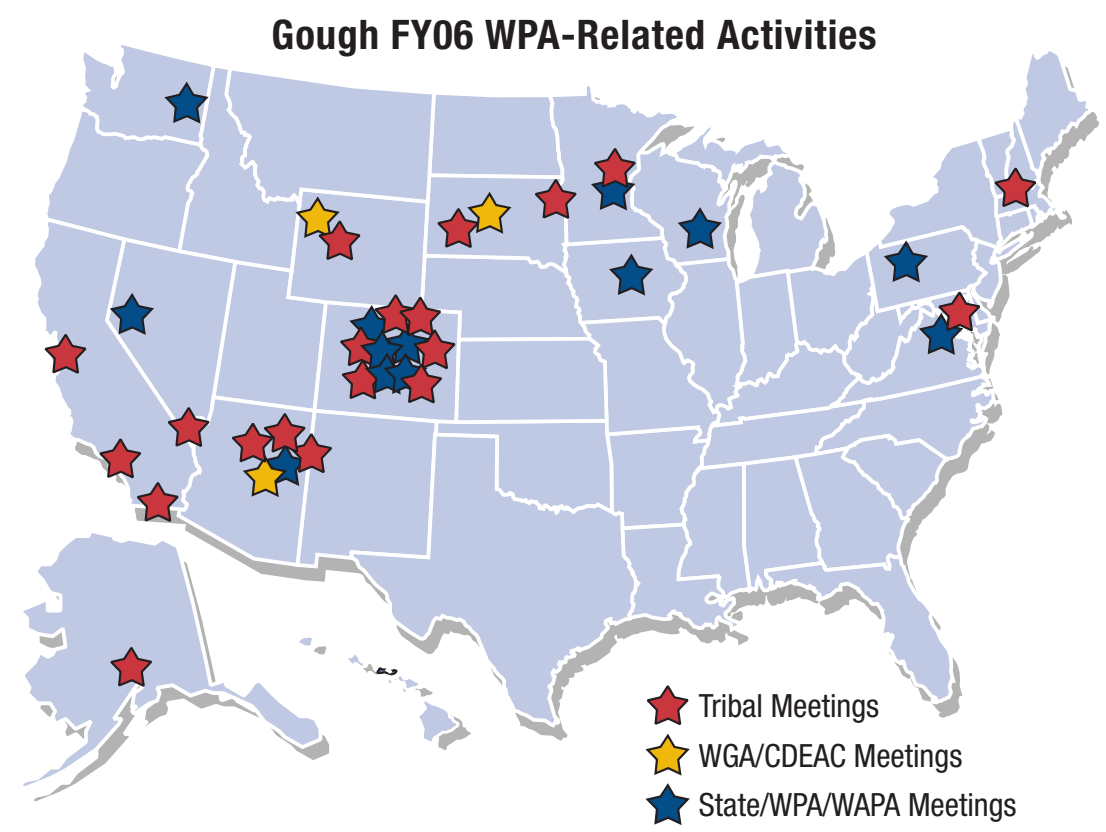

Contractor Robert Gough attended numerous meetings and events on behalf of the WPA Native American program.
BLM land and prepare a Programmatic Environmental Impact Statement. The interest level has remained high as this project has moved forward, and there are now five wind projects representing $\sim 700 \mathrm{MW}$ of wind in various stages of development and more than 70 applications for met tower installations. The U.S. Forest Service is in the process of formulating a wind development policy similar to the BLM model.

The DOE Lands Renewable Energy Assessment for wind power has begun and is scheduled for completion in mid-2007. This study targets sites in Alaska and Wyoming with Class 4 or higher wind speeds.

\section{NREL lead: Robi Robichaud}

\section{Native American Program}

Native American program activities in FY06 included the annual Wind Energy Applications Training Symposium (WEATS), talltower and short-tower anemometer loan programs, and extensive outreach.

In conjunction with the Tribal Energy Program, WPA hosted WEATS 2006 on August 8-11 at the National Wind Technology Center (NWTC) in Boulder. Total attendance was 49, of which 25 were representatives from various tribes. The remainder included representatives from federal and state agencies, as well as Mexico and the Dominican Republic. Topics included wind energy fundamentals, small wind, and large wind, and attendees also participated in a tour of the NWTC and a tour of the Ponnequin wind farm.

Four towers were installed in the tall-tower anemometer loan program, with two to four more anticipated. There is much interest in the program in Indian Country, and tribes have been creative in using loans with other grants to perform reasonable resource assessments.

The short-tower anemometer loan program is winding down, with only one tower installed in FY06.

NREL lead: Tony Jimenez

NREL contractors: Robert Gough, New Mexico State University, Pacific International Center for High Technology Research (PICHTR)

\section{Wind for Schools}

The WPA team developed and updated a new schools section of the Wind Powering America Web site that includes information on existing and planned school projects, training materials, training programs, resources and tools, and project issues.

The team also worked with Colorado school districts to educate them on requirements for a successful school wind application and to develop candidate school wind projects. The team worked with community members in 


\section{PhD Graduate Tegen to Continue Economic Development Work at NREL}

In October 2006, NREL intern Suzanne Tegen successfully defended her PhD dissertation, Electricity DecisionMaking: New Techniques to Compare Statewide Economic Impacts from Supply-and Demand-Side Solutions. She has returned to NREL as a post-doc to continue her analysis work in 2007.

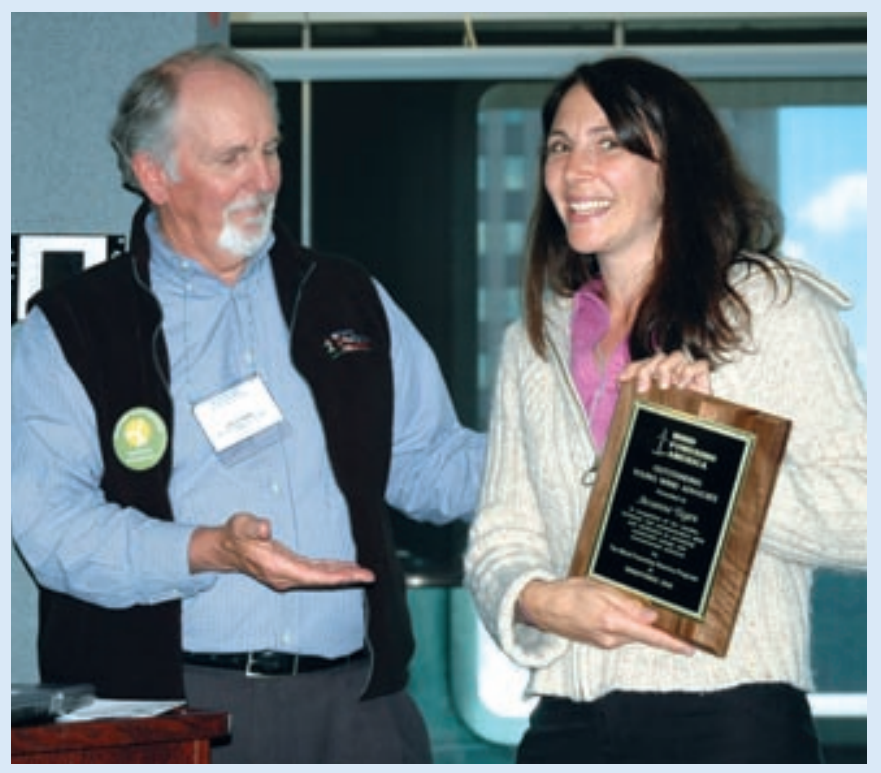

WPA technical director Larry Flowers presents Suzanne Tegen with the WPA Young Wind Advocate Award at the All-States Summit in Pittsburgh. Photo credit: Robert Gough

the town of Walsenburg, Colorado, to successfully implement a $1-\mathrm{kW}$ wind turbine at the high school.

Presentations on wind for schools were provided at a variety of local and national forums, including WINDPOWER 2006, the National Green Power Marketing Conference, the Community Wind Energy Conference, the Colorado Renewable Energy Forum, and several community meetings in Colorado and Kansas.

NREL lead: Marguerite Kelly and Larry Flowers

\section{State Outreach}

Key state outreach accomplishments for FY06 include helping to launch new Wind Working Groups in Indiana, Alaska, and Georgia.

In addition, WPA team members attended several regional events:

- Western Governors Energy Summit in Bozeman, Montana in October

- Harvesting Energy Network in Loveland, Colorado in March

- Great Lakes Offshore Gathering in Toledo, Ohio in April

- Southwest Renewable Energy Conference in Flagstaff in August
WPA also supported state events in Alaska, Colorado, Indiana, Kansas, Michigan, Montana, Nevada, North Carolina, Ohio, Oregon, and Utah.

WPA Technical Director Larry Flowers made presentations in Alaska, Arizona, Colorado, Idaho, Indiana, Iowa, Kansas, Michigan, Montana, Nevada, Ohio, Oregon, Pennsylvania, and Texas.

NREL lead: Larry Flowers

NREL contractors: Union of Concerned Scientists, Western

Resource Advocates, Bob Anderson, Tom Potter, Van Jamison, MRG \& Associates, Michael Milligan, Michael Costanti, American Corn Growers Foundation, and Environmental Resources Trust Inc.

\section{Wind and Radar}

The subject of wind and radar has been a high priority since March 2006 when the U.S. Air Force/Department of Homeland Security Joint Program Office (JPO) issued a letter contesting all wind turbine installations that could be seen by radar installations until the Department of Defense (DOD) assessed the impacts of wind farms on military readiness. This affected more than $1000 \mathrm{MW}$ of planned installations, many in the Midwest. DOE, the Federal Aviation Administration (FAA), and DOD met several times during the year and worked together to develop new guidance and long-term processes. Developers and the American Wind Energy Association (AWEA) were involved in the process, and JPO issued updated guidance in June 2006, changing the language to a case-by-case assessment. The FAA, developers, DOE, and the JPO worked together to clear the backlog. Fewer than $50 \mathrm{MW}$ are still in review; the rest of the blocked projects have been released for construction.

Two joint technical and policy committees involving the DOD, DOE, FAA, Department of the Interior (DOI), and other affected agencies were developed during the summer. Initial scope and goals are in place, and the next meetings are scheduled. Radar manufacturers have identified technical mitigation processes for integration into radar systems to improve coexistence and reduce impacts.

The DOD wind farm impact on military readiness report was released for Congress in October. DOE (Idaho National Laboratory, NREL, and EERE) pulled together a team of experts and provided detailed technical and policy review comments and submitted them to the DOD team. Experts included radar experts from the United States and the United Kingdom. Comments were integrated into the released report. INL is compiling mitigation experiences and future work into a mitigation summary. Wind radar impacts, future integration, case studies, and radar mitigation research elements are being planned and implemented for FY07 and later years. 


\section{WINDPOWER 2006 Presentations and Posters}

WPA team members presented 14 posters and papers at the WINDPOWER 2006 Conference in Pittsburgh, Pennsylvania, June $4-8$. These publications can be found in the online NREL Publications database at http://www.nrel. gov/publications/.

\section{Conference papers include:}

Marketing Strategies for Distributed Wind by T. Forsyth, NREL/CP-500-40172. The solar photovoltaic (PV) industry has developed successful strategies for marketing PV as a customer-sited energy resource that range from supporting effective Federal programs and incentives to initiating state and local efforts to remove siting barriers and to build consumer confidence. This paper examines how the PV industry market strategies might be applied to the small wind industry and provides recommendations for distributed wind development that include collaborations with the PV industry. In particular, the authors suggest aligning customer-sited small wind and PV with demand-side energy strategies and emphasizing the need to address all customer-sited renewables under a cohesive distributed generation development strategy.

\section{Wind Resource Mapping for United States Offshore Areas}

by D. Elliott and M. Schwartz, NREL/CP-500-40045.

NREL is producing validated wind resource maps for priority offshore regions of the United States. This report describes the

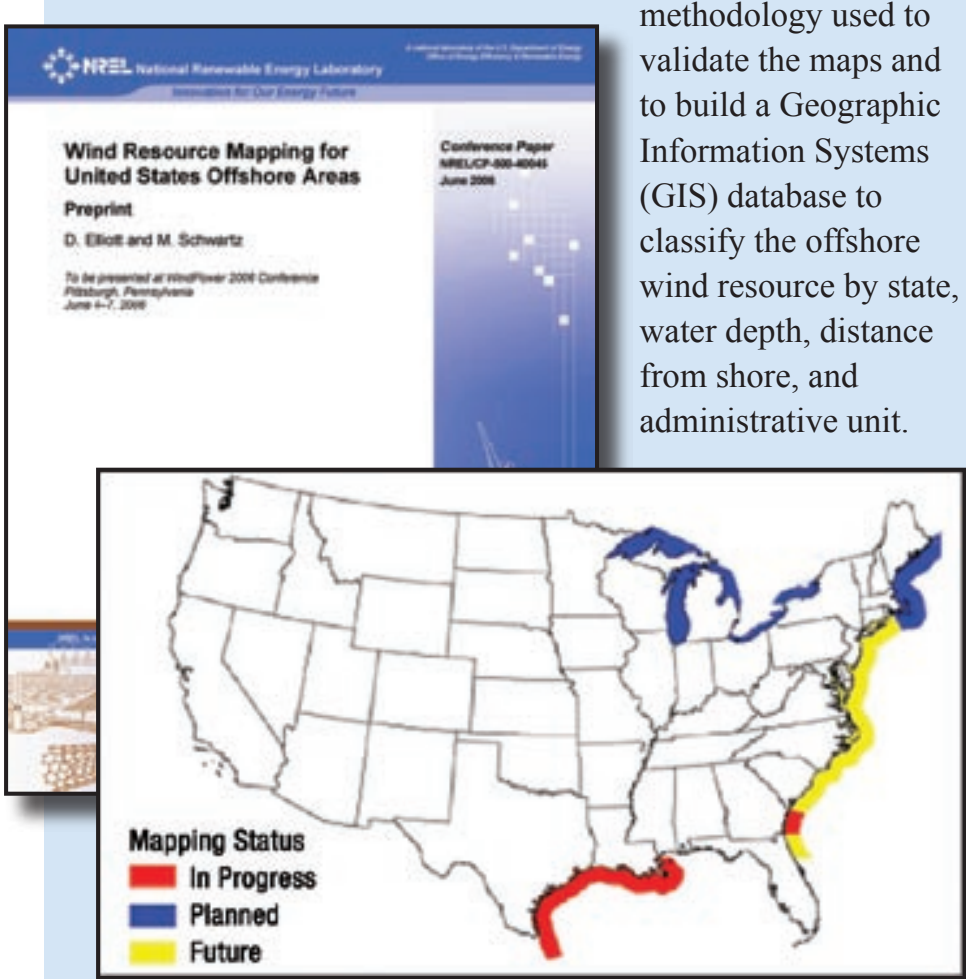

\section{Wind Shear Characteristics at Central Plains Tall Towers} by M. Schwartz and D. Elliott, NREL/CP-500-40019. The objective of this study is to analyze wind shear characteristics at tall tower sites in the central plains of the United States.

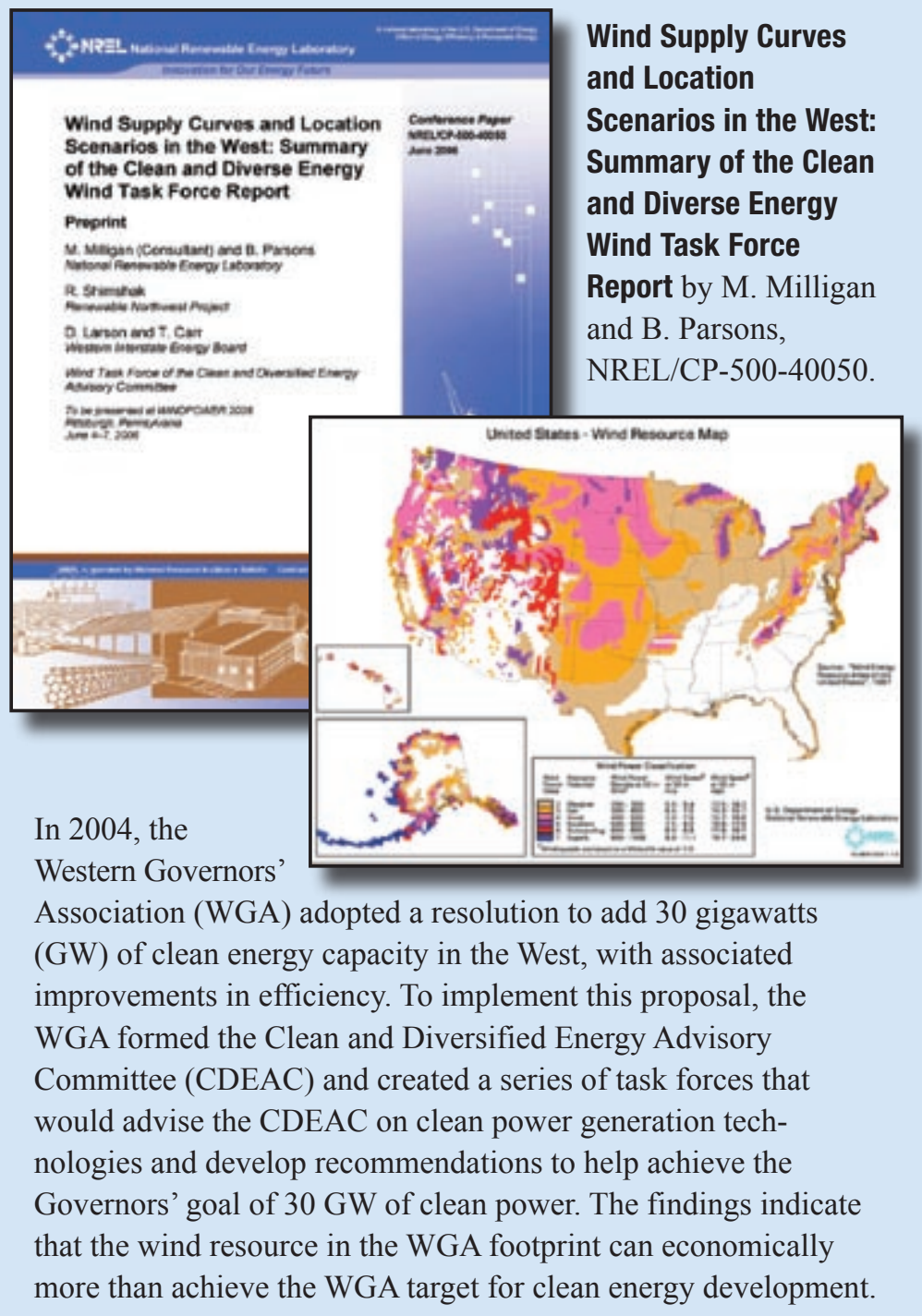

\section{User-Friendly Tool to Calculate Economic Impacts from Coal, Natural Gas, and Wind: The Expanded Jobs and Economic Development Impact Model (JEDI II) by S. Tegen, NREL/CP- 500-40085. NREL has developed new and expanded economic impact models to compare coal, natural gas, and wind power (Jobs and Economic Development Impact II, or JEDI II). The models include multipliers for jobs, income, and other impacts. Developed for statewide parameters, they can also be used to conduct a regional analysis.}




\section{Poster topics include:}

JEDI II: Jobs and Economic Development Impacts from Coal, Natural Gas, and Wind Power, S. Tegen, NREL/PO-500-39908

\section{Mapping Alaska's Wind}

Resources and Applications for Project Development, D. Elliott, NREL/PO-500-39935

Native Wind: Rural Tribes and Urban Governments Partner for Carbon Emissions Reduction Through Wind Power, T. Jimenez, L. Flowers, R. Gough, and R. Taylor, NREL/PO-500-39934

\section{Regional Field Verification} Project - Operational Results from Small Wind Turbines Installed in the Pacific Northwest, K. Sinclair, NREL/PO-500-39831

Review and Assessment of Emerging Applications for Small and Distributed Wind Systems,

I. Baring-Gould, T. Forsyth,

J. Green, and L. Flowers, NREL/PO-500-39850

\section{Wind Energy Applications} for Schools, M. Kelly, NREL/PO-500-39826

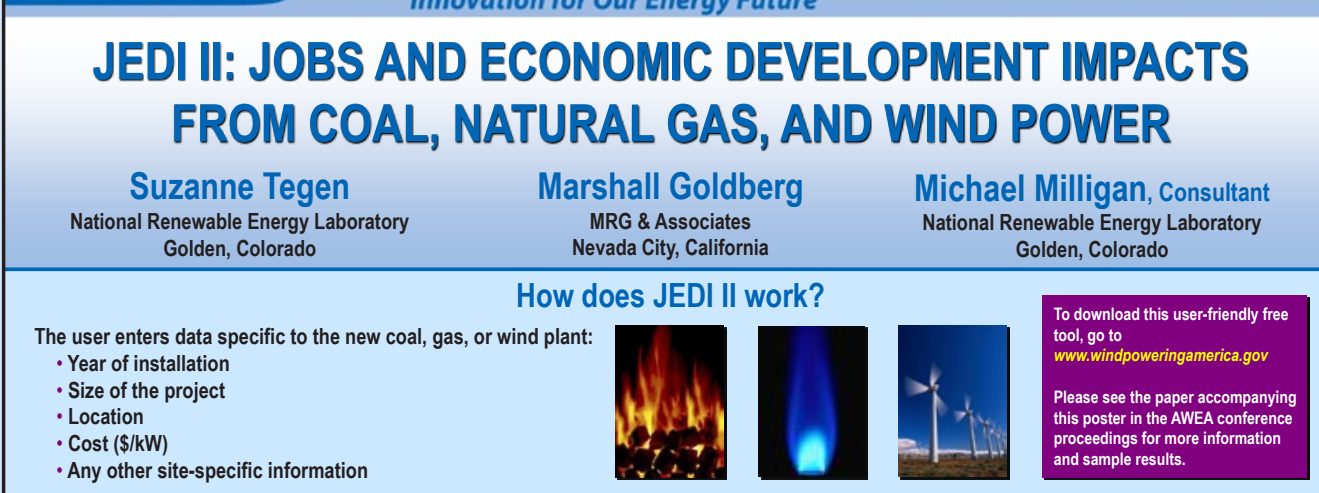

The more information the user provides, the more localized the results will be. When specific data are not available, the model uses default values.

\section{Features}

JEDI II is for all levels of users - no experience with economic modeling or spreadsheets is necessary. - JEDI II comes with on-line instructions.

Default data is available if users do not have area-specific information.

The output from JEDI II provides detailed construction and O\&M expenditure information, as well as the portion spent locally.

The model identifies local spending on debt and equity payments, property taxes and land-lease payments.

- The user may add in county or regional data to make the model more useful for their needs.

- JEDI II calculates direct, indirect, and induced impacts.
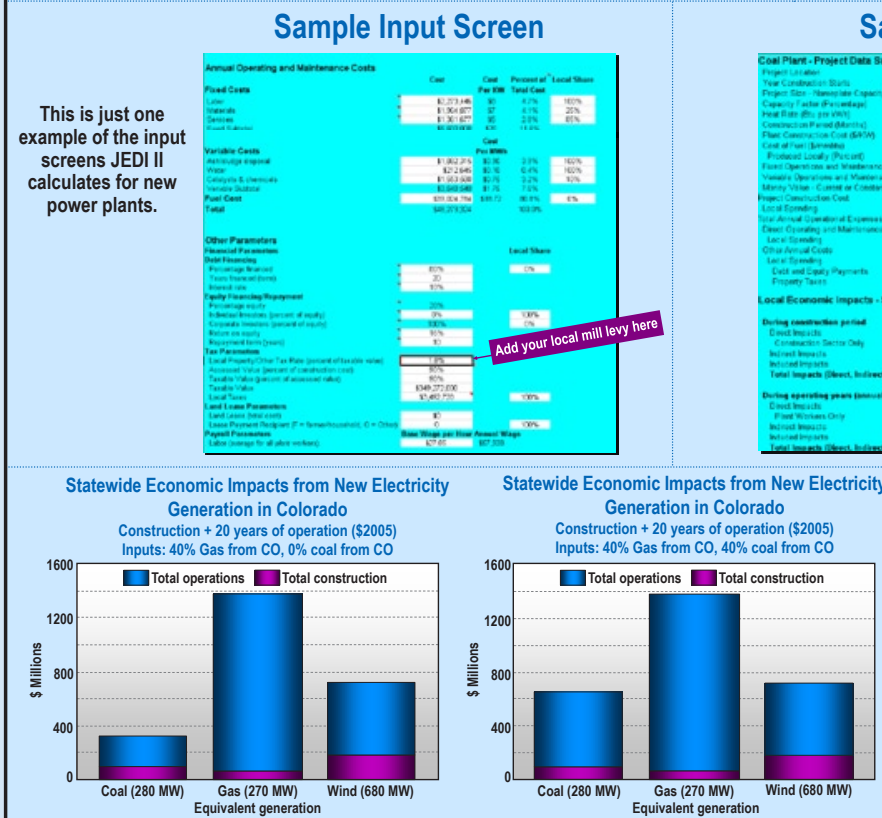

The JEDI model does not factor in costs to consumers. Fluctuations in different technologies (e. natural gas prices) may make construction of a new power plant price prohibitive.

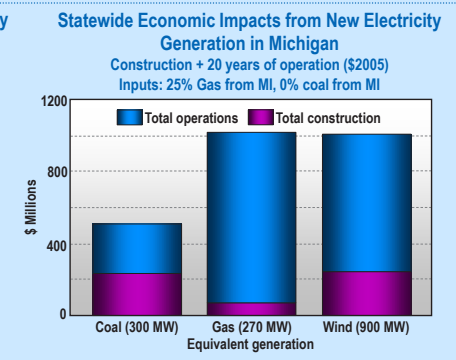

\section{Approach}

Using economic multipliers, JEDI II measures the potential employmen (jobs and earnings) and economic development impacts (output) from new power plants by calculating the dollar flow from construction and annual operations.

In its default form, JEDI II conducts state-specific analyses. County or regional analyses require additional multipliers.

\section{Sample Output Screen}

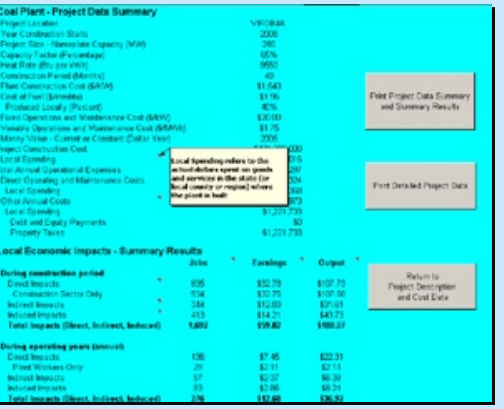
39908

Wind Powering America: 2005 Progress and Challenges Ahead,

L. Flowers and P. Dougherty, NREL/PO-500-38781

Wind Resource Mapping for United States Offshore Areas, D. Elliott, NREL/PO-500-39971

Wind-Water Nexus: Opportunities and Challenges, L. Flowers and L. Miner, NREL/PO-500-39213 


\section{Wind Powering America Web Site}

New sections were added to the WPA Web site (www.windpoweringamerica.gov) in FY06.

A Wind for Schools section was added (www. windpoweringamerica.gov/schools.asp) that highlights project locations, project models, teaching materials, training classes, and a resources and tools section.

Authored by contractor Robert Grace of Sustainable Energy Advantage LLC in Massachusetts, the New England Wind Forum sub-site made its debut at www.windpoweringamerica.gov/newengland.asp. The sub-site, which consists of approximately 50 pages of wind energy content specific to New England, is a pilot for future regional sub-sites.
WPA Web Site Visitors Per Month June 1999 - December 2006

\begin{tabular}{|c|c|c|c|c|c|c|c|c|}
\hline \multirow{2}{*}{$\begin{array}{l}40000 \\
35000 \\
30000\end{array}$} & 1999 & YR2000 & YR2001 & YR2002 & YR2003 & YR2004 & YR2005 & YR2006 \\
\hline & & & & & & & & 1. \\
\hline \multirow{2}{*}{\multicolumn{9}{|c|}{$\begin{array}{l}30000 \\
25000\end{array}$}} \\
\hline & & & & & & & & \\
\hline \multirow{2}{*}{\multicolumn{7}{|c|}{$\begin{array}{l}20000 \\
15000\end{array}$}} & & \\
\hline & & & & & & & & \\
\hline \multicolumn{9}{|l|}{10000} \\
\hline \multicolumn{9}{|l|}{5000} \\
\hline & & & & & & & & \\
\hline \multicolumn{9}{|c|}{ 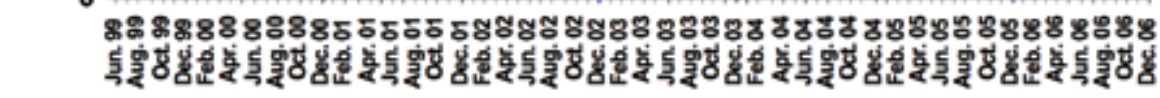 } \\
\hline \multicolumn{9}{|c|}{ 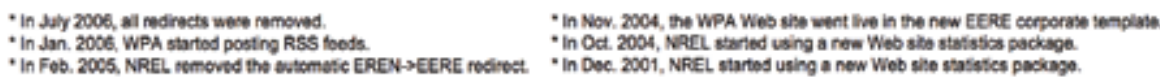 } \\
\hline
\end{tabular}

NREL lead: Julie Cardinal

NREL contractors: Julie Cardinal, Robert Grace of Sustainable Energy Advantage LLC

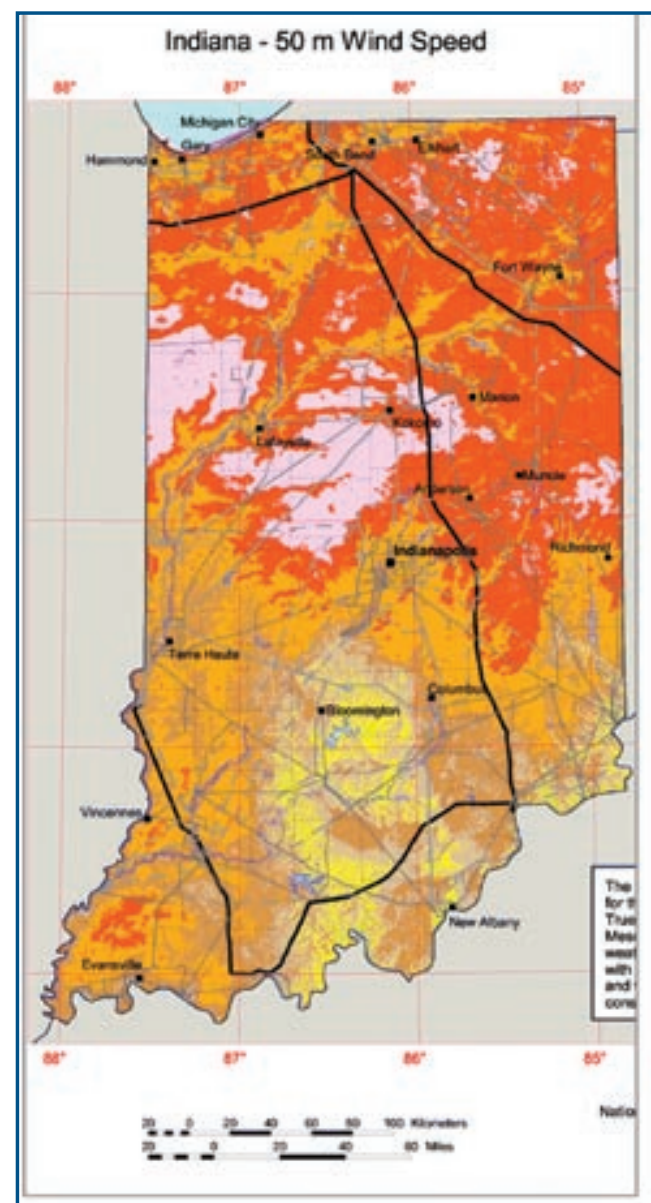

Best areas 6.5-7 m/s

Capacity factors $30-35 \%$
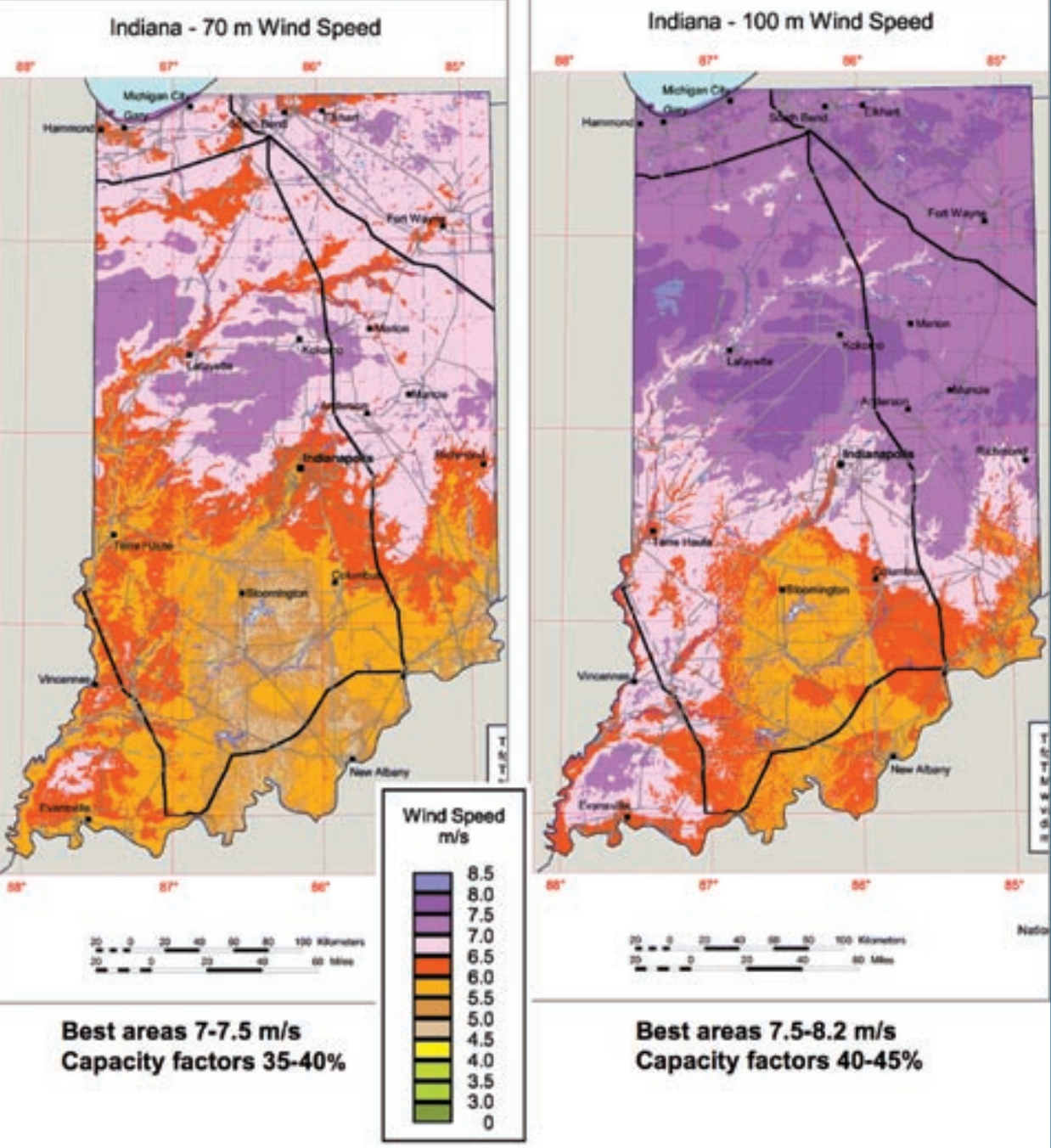

The NREL Wind Resource Assessment Team prepared these Indiana maps of the wind resource at 50 meters, 70 meters, and 100 meters. 


\section{Wind Resource Assessment}

WPA's resource assessment team engaged in the following state wind mapping and validation activities in FY06:

- Alaska: validated areas east of Anchorage and Fairbanks and completed final map for mainland regions; completed validation and final mapping for the southeastern panhandle

- Arkansas: received updated preliminary maps from AWS Truewind; nearing completion on validation

- Puerto Rico and Virgin Islands: received preliminary maps from AWS Truewind; began processing in-house data sets and identifying available data

- Georgia: preliminary mapping and validation of offshore areas completed; final maps are expected soon

- Texas and Louisiana: preliminary maps of offshore areas received; validation near completion.

The team also analyzed Indiana tall-tower data and prepared a presentation on wind resources for a preliminary RPS hearing in that state.

NREL lead: Dennis Elliott

NREL contractors: AWS Truewind, consulting meteorologists

\section{Management Activities}

The following management activities are an integral part of WPA plans:

- WPA Web site

- Advisory board

- Interns

- Presence at national conferences (such as WINDPOWER)

- Peer reviews

- Project deployment and tracking

- Analysis models

- Contract management

- Collaboration with the National Wind Coordinating Committee, the Utility Wind Interest Group, and the American Wind Energy Association.

NREL lead: Larry Flowers

NREL contractors: Ron Lehr, Global Energy Concepts

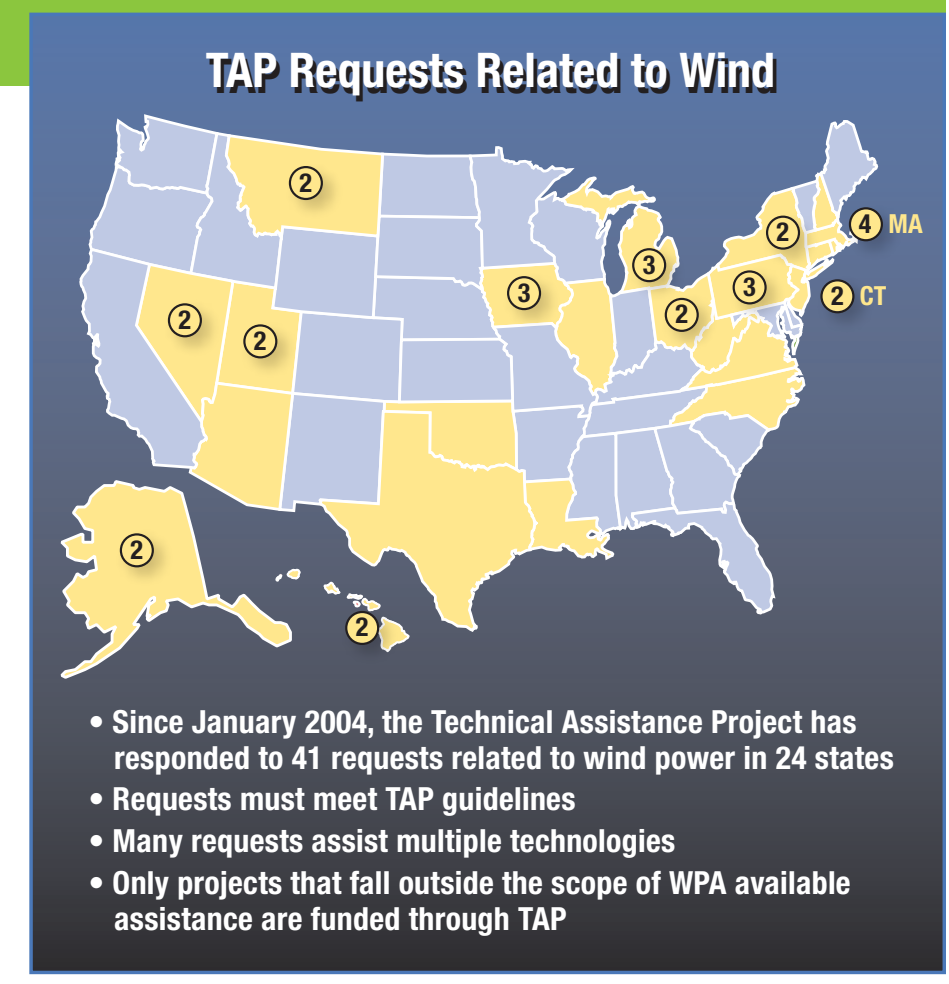

Map of locations of TAP requests

and renewable energy issues. Since its inception in January 2004, TAP has assisted with 41 requests related to wind in 24 states, and the total amount leveraged is $\$ 200,000$. (Requested assistance must not be already available through WPA or other DOE programs.) 


\section{WAPA/Public Power Partnerships}

Western Area Power Administration (WAPA) conducted activities in the areas of utility events, publications, education, national recognition for utilities employing wind energy, and grants and funding.

Randy Manion of WAPA represented the WPA Program at 11 national utility events and distributed more than 10,000 copies of wind power information to more than 3,500 electric utility representatives. WAPA published the following outreach materials:

- Wind Power for Public Power Utilities, a 14-page expanded brief on wind (in partnership with the American Public Power Association)

- Rural Electric Co-ops Working Together with Landowners, Communities, and Industry, a poster and flier (in partnership with the National Rural Electric Cooperative Association)

- An updated Wind-in-a-Box (materials on $\mathrm{CD}$ )

- Twenty-six issues of Western's Green Power News (39,000 copies distributed to more than 1,500 utilities and interested parties)

- Reprints of several WPA publications.

In addition, WAPA coordinated the 2005 U.S. DOE Wind Powering America Program Wind Co-op of the Year Award (presented to Illinois Rural Electric Cooperative Association) and the 2005 Wind Power Pioneer Award (presented to Austin Energy).

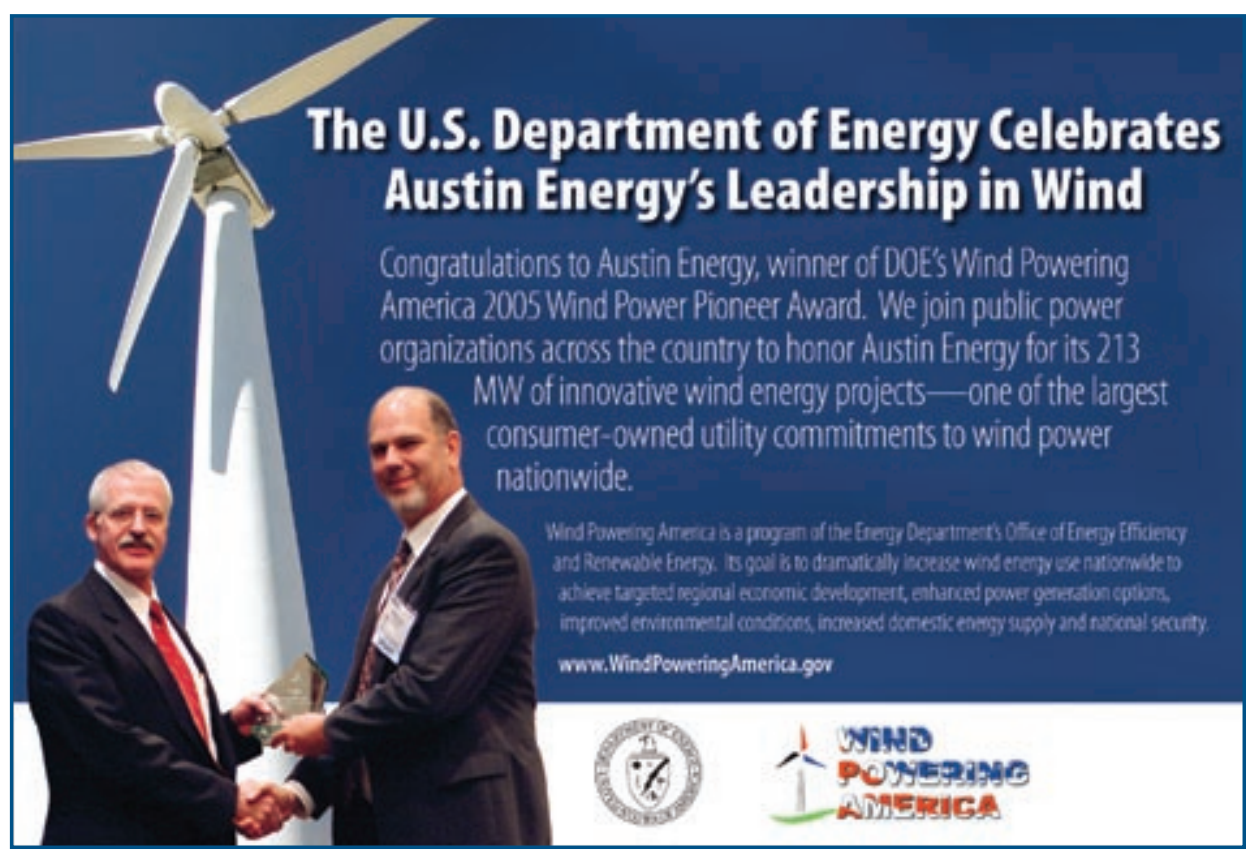

Austin Energy, the city-owned utility of Austin, Texas, received the 2005 Wind Power Pioneer Award.

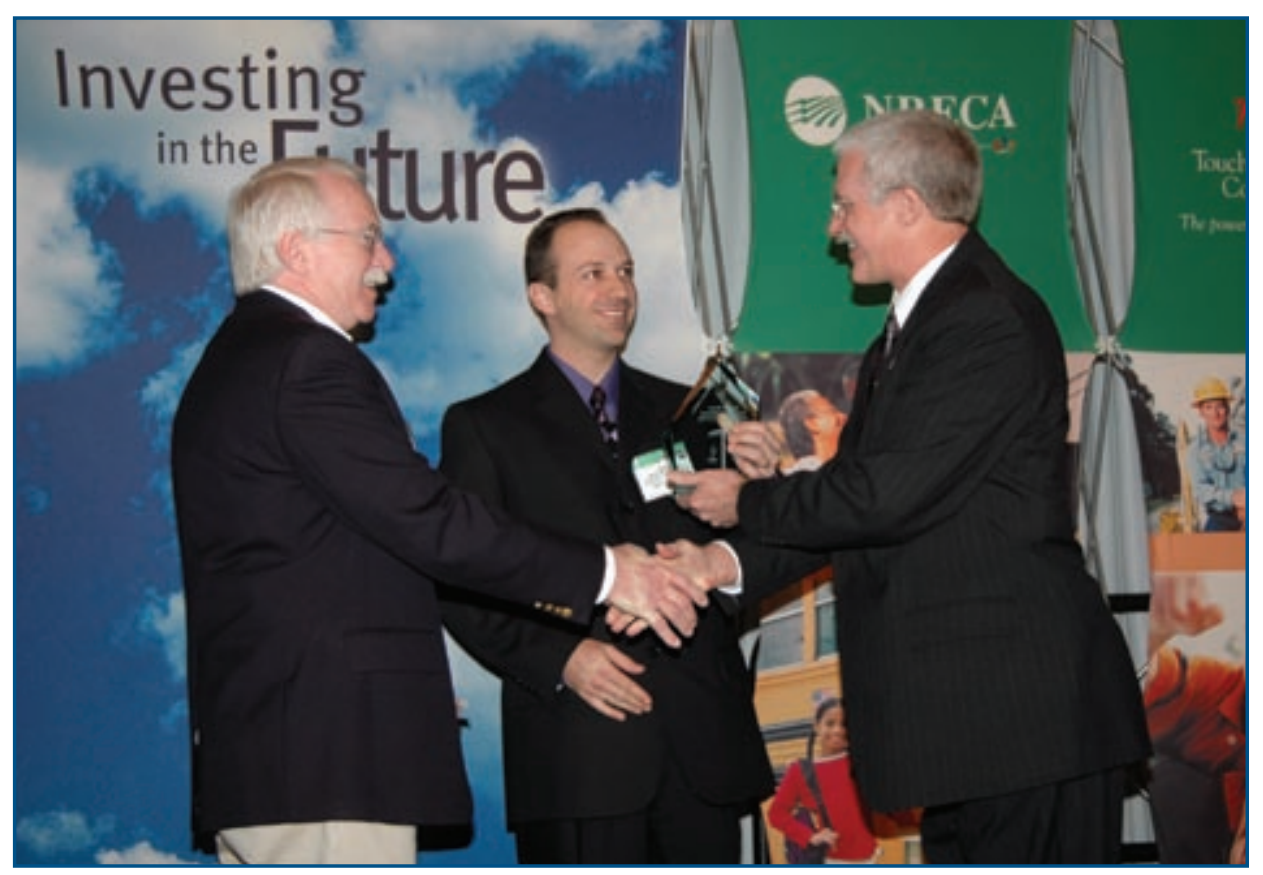

Illinois Rural Electric Cooperative received the Wind Co-op of the Year Award. 
Larry Flowers, National Renewable Energy Laboratory - Phil Dougherty, U.S. DOE www.windpoweringamerica.gov

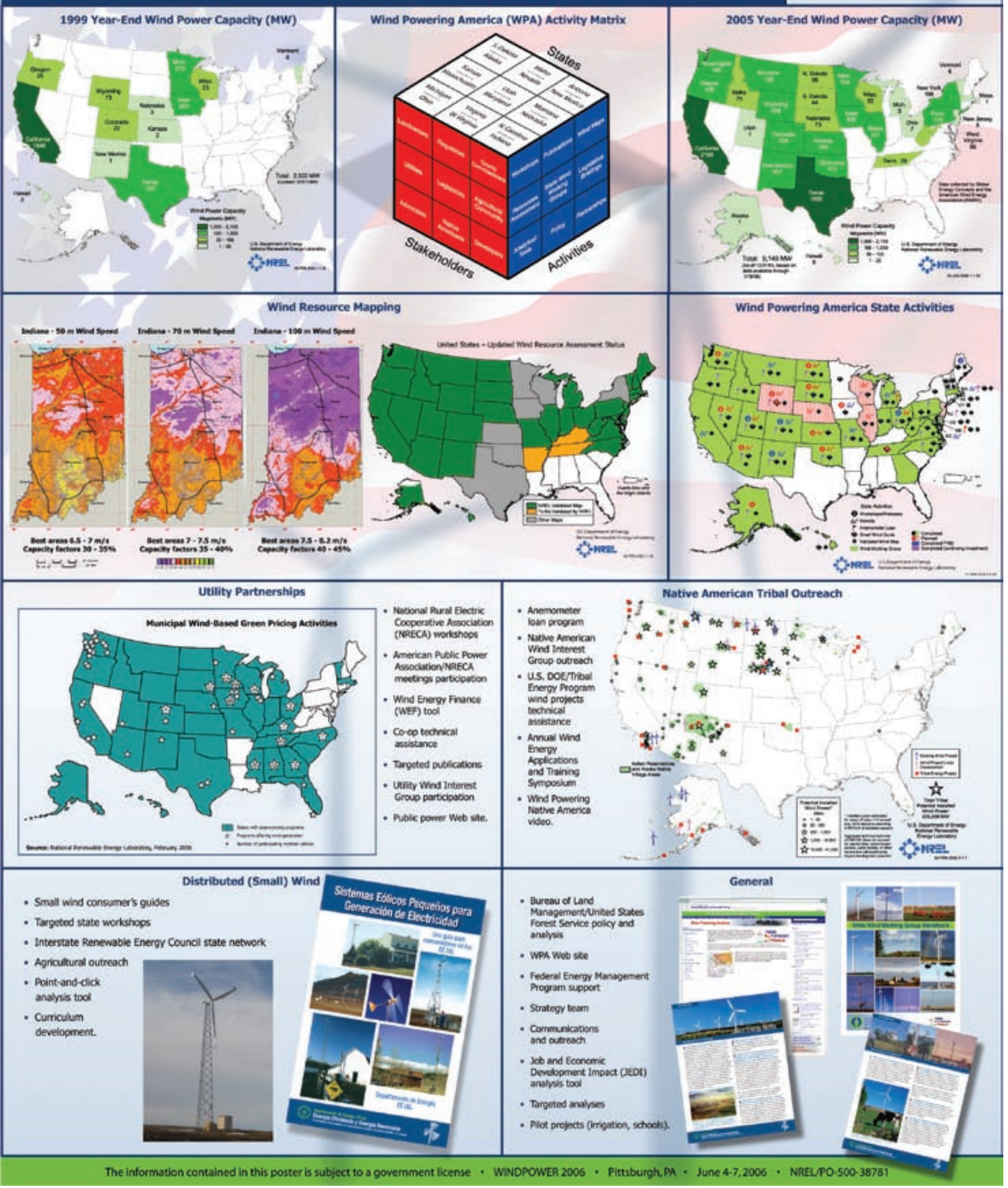




\section{A Strong Energy Portfolio for a Strong America}

Energy efficiency and clean, renewable energy will mean a stronger economy, a cleaner environment, and greater energy

independence for America. Working with a wide array of state, community, industry, and university partners, the U.S. Department of Energy's Office of Energy Efficiency and Renewable Energy invests in a diverse portfolio of energy technologies.

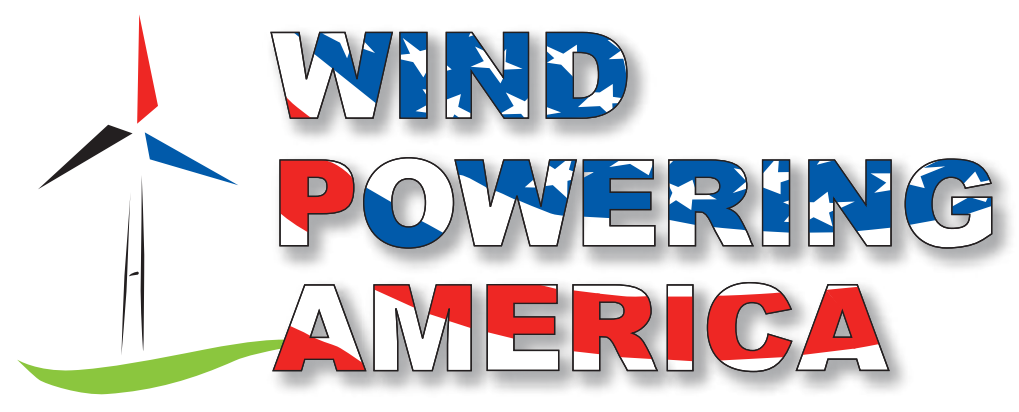

wWw.windpoweringamerica.gov

\section{U.S. Department of Energy}

\section{Energy Efficiency and Renewable Energy}

Bringing you a prosperous future where energy is clean, abundant, reliable, and affordable

For more information contact:

EERE Information Center

1-877-EERE-INF (1-877-337-3463)

www.eere.energy.gov

Produced for the U.S. Department of Energy by the National Renewable Energy Laboratory, a DOE national laboratory
NOTICE: This report was prepared as an account of work sponsored by an agency of the United States government. Neither the United States government nor any agency thereof, nor any of their employees, makes any warranty, express or implied, or assumes any legal liability or responsibility for the accuracy, completeness, or usefulness of any information, apparatus, product, or process disclosed, or represents that its use would not infringe privately owned rights. Reference herein to any specific commercial product, process, or service by trade name, trademark, manufacturer, or otherwise does not necessarily constitute or imply its endorsement, recommendation, or favoring by the United States government or any agency thereof. The views and opinions of authors expressed herein do not necessarily state or reflect those of the United States government or any agency thereof.

DOE/G0-102007-2392 • February 2007

Printed with a renewable-source ink on paper containing at least $50 \%$ wastepaper, including $10 \%$ postconsumer waste 